\title{
Materializing the Invisible: Landscape Painting in Viceregal Peru as Visionary Painting
}

\author{
Sebastian Ferrero
}

check for

updates

Citation: Ferrero, Sebastian. 2021.

Materializing the Invisible:

Landscape Painting in Viceregal Peru

as Visionary Painting. Arts 10: 57.

https://doi.org/10.3390/arts10030057

Academic Editors: Lauren Beck and Alena Robin

Received: 6 April 2021

Accepted: 17 August 2021

Published: 26 August 2021

Publisher's Note: MDPI stays neutral with regard to jurisdictional claims in published maps and institutional affiliations.

Copyright: (C) 2021 by the author. Licensee MDPI, Basel, Switzerland. This article is an open access article distributed under the terms and conditions of the Creative Commons Attribution (CC BY) license (https:/ / creativecommons.org/licenses/by/ $4.0 /)$.
Art History Department, Art and Sciences Faculty, Université de Montréal, Montreal, QC H3T 1N8, Canada; sebastian.ferrero@umontreal.ca

\begin{abstract}
Landscape painting in Peru typically does not receive much attention from critical discourse, even though the adoption of the Flemish landscape by Andean viceregal painters became a distinctive feature of Peruvian painting of the second half of the 17th century. Considered a consequence of a change in the artistic taste of viceregal society, the landscape was perceived as a secondary element of the composition. In this article, we will analyze the inclusion of the Flemish landscape in Andean religious painting from another critical perspective that takes into account different spiritual processes that colonial religiosity goes through. We analyze how the influence of the Franciscan and Jesuit mysticism created a fertile ground where landscape painting could develop in Peru. The Andean viceregal painters found in the landscape an effective way to visualize suprasensible spiritual experiences and an important device for the development in Peru of a painting with visionary characteristics.
\end{abstract}

Keywords: Peruvian viceregal painting; religious painting; landscape; mysticism and contemplation

\section{Introduction}

In the second half of the seventeenth century, viceregal painting in Peru began a period of aesthetic transformations conducted by the painters of $\mathrm{Cuzco}$-mostly mestizo and indigenous - and spread to other parts in the South Andes. One of these aesthetic changes consisted of reducing the use of monumental human figures to give more room to the representation of landscapes. In order to resolve this compositional space, viceregal painters turned to the Flemish-style landscape model, which was rooted in the Weltlandschaft ${ }^{1}$, a pictorial tradition that began with Flemish painter Joachim Patinir that was characterized by representations of idyllic or imaginary panoramic landscapes, privileging distant open glances and bird's-eye perspectives. These views contain a series of motifs such as rugged mountains, blue skies, distant horizons, small forests and fields, serpentines rivers, castles, and huts, all framing little religious episodes, pilgrimages, and hunting scenes. Weltlandschaft (panoramic world or world landscape) appears as a reduced representation of an entirly visible universe. Over time, this kind of landscape would be simplified to a series of archetypal motifs, producing more and more idealized and delocalized vistas ${ }^{2}$. The adoption of the Flemish landscape by viceregal painters was generally explained by the circulation of visual models from northern Europe in Peru, as well as by a change in the artistic taste of viceregal society ${ }^{3}$. Surely, much of this is true and essentially seems irrefutable; however, the axiomatic nature of these premises prevented a more careful and in-depth look at this phenomenon. In other words, the linearity with which the transfer of landscapes is regarded-from Flemish engravings to Cuzco paintings-unfairly dismissed a possible interest of viceregal painters towards landscape painting and, above all, underestimated the importance of this element in the narrative framework of the paintings.

Indeed, the almost exclusive use of this style of landscape by Andean painters and, consequently, the minimal presence that was granted to the local landscape led some art historians to claim that viceregal painters were completely disconnected from their natural 
environment and daily reality. Therefore, they reproduced imported models without readapting or re-signifying them.

For example, discussing the Cuzco school of painting in the second half of the seventeenth century-in particular, the representation of the landscape and the pictorial space of religious paintings - the Italian-Venezuelan historian Graziano Gasparini stated in the 1970s that the copy of Flemish landscapes revealed a total rupture between viceregal painters and their natural and sociocultural environment. Gasparini had hoped to find spatial references in Andean paintings from the local countryside, but he only found landscapes of European influence. According to Gasparini, this disconnection between the artist and the geographical and social environment is explained by the fact that "in almost every case [the viceregal painter] is dealing with a direct contribution which passively carries out, with greater or lesser ability, systems of constructions and concepts of form which have been imposed by the dominant culture" (Gasparini 1978, p. 280).

Beyond the historiographical place where Gasparini pronounces this judgment, demonstrating some of the excesses that led to the old theme of originality/dependence on viceregal art, the absence of Andean elements in the pictorial spaces of Cuzco painting was, for many historians and not only Gasparini, a fundamental factor in relativizing the "social conscience" of viceregal painters with their reality ${ }^{4}$. On the other hand, it proves the little importance that landscape painting had as a genre in viceregal artistic production.

This analysis is based, of course, on the idea that landscape painting in the 16th and 17th centuries should be considered as an independent pictorial genre that began as a consequence of the interest of a group of painters from Flanders in depicting the world that surrounded them as an aesthetic spectacle. The landscape was understood as a pictorial genre destined for the pleasure of the gaze, devoid of every religious meaning ${ }^{5}$.

If we analyze the appearance of landscapes in Andean painting under this theoretical context, it is difficult to suppose that the practice of landscape painting in Peru has a specific weight and can be valued instead of being considered a secondary or decorative element.

However, it is unfair to claim that viceregal painters were passive recipients of the Flemish landscape painting and, above all, to pretend that they were totally disconnected from its sociocultural reality. It is not necessary for viceregal painters to speak of a reality that identifies or represents themselves or to be aware of their space and their sociocultural context (which, at that time, let us not forget, was the colonial system); viceregal painters were obliged to include in their paintings local elements or landscapes that-only in the eyes of Europeans-defined a kind of Americanness. Jorge Luis Borges has already said it: "The Koran has no camels" (Borges 1957) and yet it is still Arabic ${ }^{6}$. In other words, the Flemish-style landscape could also be significantly related to the cultural and religious universe that was lived in the Andes at that time.

It is undeniable, of course, that the "camels" of viceregal paintings were visible on many occasions. Indeed, towards the end of the 17th century, the views with rugged mountains and walled cities of idealized Flemish landscapes are enlivened with fruit trees, grounds draped with flowers, and skies inhabited by fanned, colorful birds. Many of these new elements could be related to local nature. Andean species of fauna and flora could be identified, such as vizcachas and kantuta, ñucchu, or amancay flowers, as well as a large number of jungle birds, parrots, and some Andean goldfinches. The luxurious nature that invades the prototypical Flemish-style landscape led some art historians towards the tropicalization of the Andean viceregal landscape by connecting these species to the eastern Peruvian jungle, which was identified as the Inca Antisuyo region ${ }^{7}$. According to these authors-especially art historian Teresa Gisbert-this transformation of the landscape is due in part to the missionary discourse that sought to relate the Andean concept of the world above or the upper world (Hanaqpacha) to the traditional image of the flowery orchard of Heaven's Paradise (Gisbert 2008, pp. 150-51). Likewise, it was believed that, in this luxurious nature that overwhelms Andean religious paintings, some Creole discourse that made Peru the promised land that housed the lost Eden could be seen (Gisbert 2008, pp. 155-61). Certainly, these elements deserve a more detailed analysis; however, this 
is not the objective of this article, but it is rather to understand how the phenomenon of the inclusion of the landscape in Andean religious painting occurred, the reasons for its typification, and the meanings that the landscape may acquire within the colonial context for painters and viewers. Likewise, we claim that the use of foreign aesthetic forms does not necessarily mean a sign of dependence, but quite the opposite. Once implemented in a new context, they become genuine and novel elements. As we have just stated, even if it was often possible to identify the representation of Andean species of fauna and flora in 18th-century viceregal canvases, the landscape continued to be almost exclusively of Flemish inspiration. For this reason, the purpose of some specialists who advanced the idea that, at some point in the history of viceregal painting in Peru, there was a kind of emancipation of the European landscape could also be overstated ${ }^{8}$. It was as if there was an awakening in the viceregal painters, an impulse to place the divine and biblical characters of religious painting in a more "recognizable" setting, moving them from idyllic Flemish landscapes to more tropical or mountainous settings. This seems to be the opinion of Flores Ochoa, Elizabeth Kuon, and Roberto Samanez, who assured that, from the end of the 17th century, "[t] he [viceregal] painters stop copying urban scenes and European landscapes to situate their religious themes and moralizing content in familiar cities and in recognizable environments" (Flores Ochoa et al. 1993, p. 228) (our translation).

The impact of Flemish-style landscapes on Andean painting does not mean that the practice of landscape painting in Peru was not determined by local needs and realities, even if the aesthetic model was foreign. In other words, the genuineness of landscape painting in Peru was not dictated by the emancipation of the Flemish aesthetic, but rather how it was appropriated and how this appropriation rejoined the needs of colonial space-time. To understand this, it is first necessary to break with the perception that the Flemish landscape in Peru was celebrated solely for its artistic value and, therefore, reproduced out of a need to adapt the canons of viceregal painting to the European aesthetic formulas that were in vogue. In reality, although some colonial chroniclers, eager to raise the quality of local artists, be they Creole, indigenous, or mestizo, recognized intheir ability to reproduce landscapes ${ }^{9}$, the aesthetic valuation of Flanders landscapes, this is not necessarily the unique motivation that moves viceregal painters. We must point out that the most common contact that viceregal painters had with the representation of landscapes was through the backgrounds of the engravings with religious scenes coming mainly from Flanders. Linking the landscape to religious themes was common, and this linkage increased its symbolic value and the indivisible nature between the landscape and the divine. The Flemish landscape brought a conceptual factor that prevails above all aesthetic or imitative valuation. This is decisive in the use of landscapes in viceregal painting. Once the translatio was produced, this meant that the Flemish landscape broke into viceregal painting and left room for the appearance of inventio; thus, this pictorial element became validly genuine. This invention of which we speak is not necessarily characterized by a transformation of the European components of the landscape, no matter how little that was, but rather by a conceptual appropriation and reuse of the landscape in different compositional contexts for which they had not originally been created.

Landscape paintings in the Andes incorporated all of this symbolic meaning from Europe-either its exegesis or the power it had to transmit states of deep inner spirituality. This capacity of landscapes to visualize metaphysical experiences explains the use of landscapes in Peruvian viceregal painting. In other words, landscape painting was one of the privileged ways in the Andes to conceive visionary painting.

The historical processes that explain the appearance of the landscape in Peru are very similar to those that gave rise to this genre in Europe: the influence of the pastoral, the catechism, and the ideas of mysticism related to contemplative exercises through nature, which were promoted in the physical philosophy of Saint Augustine (354-430), the mystical theology of Pseudo-Dionysius the Areopagite (5th or 6th century), the Itinerario of Saint Bonaventure (1221-1274), and many of the Spanish mystics, such as Saint Ignatius of Loyola or Saint John of the Cross (1542-1591), to mention only a few. 
In the Andes, the mid-17th-century renewed pastoral, which was denoted by the publication of Jesuit Father Francisco de Avila (c. 1573-1647) Sermonario (c. 1648), seems important for stimulating the practice of landscape painting. Likewise, the mystical exercise of contemplation through creatures offered good possibilities to colonial missionary fathers to build points of contact between mystical panentheism and ancient Andean pantheistic beliefs.

In this article, we will first study some European models in situations where the landscape acquires the function of representation of ecstatic behavior. This will allow us to determine the circulation of ideas and artistic models. We will then study how the mystical use of landscape painting in the Andean context became one of the most innovative elements of Andean compositions by transforming even the visual sources used by viceregal painters and updating the meanings and narrative content of the religious scenes they represented. We argue that landscape painting in the Andes was a pictorial component that, based on the spiritual meaning that mystical thought placed on nature and creatures, allowed viceregal painters to use it as a valid form of representation or visualization of invisible phenomena.

\section{Mysticism and Contemplation of the Book of Nature in Peru}

Before dealing with the analysis of landscape painting in the viceroyalty of Peru, it is prudent to first briefly examine the historical and spiritual context that, in our opinion, explains the use and increasing importance of landscape painting in the Andes.

It is well known that the mystical fervor manifested in the Iberian Peninsula in the 16th century was transferred to the viceroyalties with great impetus. Even in Peru, mysticism showed an endurance that exceeded the metropolis. It is not surprising that even in the middle of the 18th century, when mysticism was in clear decline in the peninsula, Creole authors, such as the Franciscan Fray Juan de Peralta, published Las tres jornadas del cielo: via purgativa, iluminitiva i unitiva, a book that followed El Cantico Espiritual ${ }^{10}$ of Saint John of the Cross and the Pia Desideria ${ }^{11}$ of the Jesuit Hermann Hugo closely. All of these works narrated the soul's travel, with the guidance of the Beloved (Christ), through a thick spiritual forest to reach the divine union or divine marriage between the soul and Jesus. In this same manner, we mention the numerous series of paintings executed from the seventeenth to the nineteenth centuries that reproduced the engravings of different editions of the Pia Desideria ${ }^{12}$ and, to a lesser extent, the books of emblems about the divine love, such as Emblemata Amatoria (1601) by Daniël Heinsius (1580-1655) and Amorum Emblemata (1608) by Otto Van Veen (Vaenius, 1556-1629), which mainly decorated the churches, convent cells, and cloisters of novices and nuns.

In addition to the patriotic spirit that encouraged it, the large number of mystics and blessed servants of God who emerged in Peru (principally in Lima) can be attributed to this mystical fervor; among these were: Santa Rosa de Lima (1586-1617), San Francisco Solano (1549-1610), Antonio Ruiz de Montoya (1585-1652), Francisco del Castillo (1615-1673), and others (Mujica Pinilla 1995, p. 54). Many illuminated women (alumbradas), beyond all the mistrust that they generated in the ecclesiastical authorities, often appeared in Lima, declaring visions and constant bliss with the desire to follow the path of divine love (Mujica Pinilla 1995, 2005).

In this article, we are particularly interested in the influence that Franciscan mysticism had in Peru, a current of thought that used the contemplation of nature as a fundamental method for achieving divine love. The Jesuits, however, were likely the most responsible for the dissemination of these ideas.

These concepts were adopted by the Andean pastoral from very early on. At first, the missionary discourse sought to replace Andean pantheism, insisting on the creationist aspect and the utilitarian role of nature as being created at the service of man ${ }^{13}$. After this, the catechisms gradually incited the exercise of contemplation of nature to find in it a new meaning and essence. For example, the Tercero catecismo (1585), published as a consequence of the III Council of Lima of 1583, gradually introduced the idea that nature is 
a contemplative space, a direct channel between man and God. The Tercero cathecismo taught the newly converted indigenous Christians acute or pious use of the senses-in particular, the sense of sight-and incited them to "look at" the phenomena and beauties of nature, since in their magnificence resided the footprint of the true God (ibid., pp. 51-52). This principle of cohesion between nature and sacred space came from medieval scholasticism of considering nature as the second book of God.

Despite this, the Tercero cathecismo was still close to the creationist spirit of the first missionary discourses. It was in the Symbolo catholico indiano (1598) by Franciscan Father Luis Jerónimo de Oré (c. 1554-1630), born in Huamanga (current Ayacucho), that the ideas linked to the contemplation of the book of nature (liber mundi or liber naturae) were introduced in the Andean pastoral.

The Symbolo begins, as the Tercero cathecismo, by discussing the knowledge of God (García Ahumada 1990). However, the Franciscan Father argues that this knowledge is obtained from the contemplation of nature: "The knowledge of God is reached by the consideration of creatures, although more perfectly with a light of revelation" (our translation) (Oré 1598, p. 3). This implied inquiring into the essence of nature with the senses of the soul. Ore divided this "divine book of nature" into four parts or "pages" that were ordered from inanimate things (the four elements, which have an entity), plants (with entity and life), animals (which have an entity, life, and feeling), and man (for whom everything else has been created and who has entity, life, feeling, and understanding). Finally, angelic creatures came as the last step that separated God from man (Oré 1598, p. 2v-7r; García Ahumada 1990, pp. 928-29). Among the many authors who wrote on this scala naturae ${ }^{14}$, the greatest influence for Oré must have been the Spanish mystic Fray Luis de Granada and his Introducción al Simbolo de la Fe, when he stipulated that "the order of creatures leads us to the knowledge of its principle" (Granada 1856, p. 188).

Even though Oré's catechism was recognized and demanded for parochial use in some Concilios Sinodales of Cuzco and Huamanga (Durston 2007, p. 148), mystic ideas were inserted into the Andean pastoral as the sense of the soul, contemplation, or the use of potencies took force in the middle of the seventeenth century with the publication of the Tratado de los Evangelios of the Jesuit Francisco de Ávila (1648). Beyond Oré's influence on the Avila catechism, his work sought to introduce the Spiritual Exercises of Saint Ignatius into pastoral practice. The Tratado accorded an important place to the mystical soul and to the use of the soul's senses, which were deemed necessary in order to find and carry out contemplative exercises. In various moments of his sermonario, Francisco de Ávila taught the indigenous people to look with their inner eyes and to deprive themselves of their bodily senses in order to reach the contemplation of God.

With those eyes of the soul, the retreatant had to look at all created things. For this reason, the indigenous chronicler Pachacuti Yamqui represented seven eyes (the image of the seven virtues) in his famous cosmological drawing, which is supposedly a reproduction of a gold plate of the Coricancha (Temple of the Sun). Beside this motif, he added a legend that says: "ymaymana ñaoraycunap ñauin" ("los ojos. Todas las cosas. Los ojos de todas las cosas," the eyes. All things. The eyes of all things)"15. With this legend, Pachacuti meant that the eyes represented the vision that should be used to see all things, that is, the eyes of enlightened understanding. This kind of vision, as suggested by Pachacuti Yamqui, would have been used by the first Incas, such as Manco Capac and his grandson, Mayta Capac, to reach the knowledge of the true God (Ferrero 2018, p. 36).

In order to support pastoral Avila's method, the Augustinian father Miguel de Aguirre considered in the "Aprobacion" of the Tratado de los Evangelios, that the application of physical philosophy in pursuit of knowledge of the Christian God is an essential tool in the education and evangelization of new Christians. Miguel de Aguirre thus established a parallel between the religious education of Saint Augustine and the spiritual education of the indigenous people.

Saint Augustine says about himself that he could only reach at the beginning of his conversion the knowledge of the invisible creator through his visible crea- 
tures and that he could not pass from there nor perceive the Mystery of the Incarnation [ ... ]. So, if the Phenix of the wits, recently converted, could not perceive the Mystery of the Incarnation, what could a barbarian Indian understand, if we preach to him curious and delicate sermons [ . . ],?. (our translation) (Aguirre 1648, p. 2v-3r)

According to Aguirre's opinion, the "Indians," although they were not prepared to understand difficult theological mysteries, could undertake the spiritual path beginning with the knowledge of God through his creatures, as Saint Augustine had done. As we have noticed in Luis Jerónimo de Oré, this knowledge implied traveling the ascending path or ladder to reach contemplation. This passage by Miguel Aguirre also recalls that the invisible could be accessed through the visible universe. In other words, the invisibility of its creator could be visualized through nature. All of this process ensured union with God in life, without waiting for salvation in Glory. The position taken by Aguirre exemplifies the phenomenon that was gaining a place in the construction of the evangelical discourse of the mid-seventeenth century, making the contemplation of nature a powerful Christian pedagogical tool.

For the indigenous peoples, who tried many times to position themselves within Christianity $^{16}$, "the book of nature" offered a democratized space in which they could demonstrate their piety or Christian zeal. It was not necessary to be a scholar or to have theological knowledge to reach the true God. Even the Incas, as the Andean chronicler Joan Pachacuti Yamqui attempted to prove practiced contemplation with enlightened intellect through the "book of nature". This allowed the sovereigns of the Tawantinsuyo to keep the Natural Law (intrinsic moral values given by God to the human being) intact before the arrival of the gospel in America and could even hope for salvation at the end of time (Ferrero 2018, 2021). If, as we have pointed out, the numerous series of the Pia Desideria revealed the success of mystical themes in Peru, the location of some of these series in some indigenous parishes, such as in the Altiplano Church of Jesus of Machaca (La Paz) and the Cuzco churches of Checacupe (Quispicanchis) and San Pedro (Cuzco) ${ }^{17}$, warns us of the strong presence of mystical themes in the Andean pastoral discourse.

Another element to take into account is the possible cohesion between the panentheistic ideas that emerged from the Franciscan mysticism and the Spiritual Exercises of Saint Ignatius with the ancient Andean pantheistic beliefs (Ross 1992, pp. 111-12). Of course, the mystics did not deify nature per se, that is, they did not venerate its sensitive and visible aspects, but rather granted a divine essence to all creatures. This difference was conceptual or philosophical, but the object of veneration was still nature. In other words, mysticism found in Indigenous pantheism a propitious ground to plant its seed.

It is in this theological and pastoral context that the representation of the landscape began to assert itself in religious viceregal painting, gaining a more prominent space in pictorial compositions. This missionary discourse may have impacted the ways of considering visual representations of the natural world through landscape painting. The viceregal painters were not oblivious to these speeches, experiencing this same religious sensitivity regarding the contemplation of the landscape. The landscape was not a secondary, anecdotal, or decorative element, but rather, it was used as an iconographic motif bearing its meaning, which was forged from the very first and foundational importance that mystical theology gave to nature as a space for contemplation and revelation. As an iconographic motif, it was able to establish narratives and meanings with the other elements of the composition. Landscape painting within various religious scenes was presented as a logical solution for representing the sacred aspect of nature and its importance as a source of knowledge. The landscape also served to visualize the suprasensible aspect of the exercise of contemplation, which involved an introspective process where the exerciser transited through the potencies of the soul, which required, as Oré argued and Francisco de Ávila taught to the indigenous people, reaching the "enlightened intellect." 


\section{Using Landscape as Visionary Subject in the European Context}

If the main literary ideas of viceregal mysticism came from Spain, as far as visual models are concerned, Flemish paintings and their symbolic use of landscape seem better for translating the sentiment of Andean colonial spirituality. We are not just talking about style-related issues. The stylistic impact of the Flemish landscape in the viceregal painting is a fact that has been proven, so it is not necessary to return to this topic (see Mesa 1994; Stastny 1997, p. 116; Mariazza Foy 2012). We refer particularly to the visionary aspect that could emerge from the landscape, which is handled more as an iconographic motif than as a scene or pictorial space. The interpretive clarity revealed by the examples studied here improves the understanding of the symbolic value that the landscape acquires within the context of South Andes viceregal painting.

Unlike visionary Spanish painting, where scenes of ecstasy and raptures were privileged in gloomy spaces and interrupted by breaks of glory and lighting effects (scenes more related to infused contemplation) (Stoichita 1996), the viceregal painters, on the other hand, without being averse to this type of representation, often used landscapes as a narrative solution to construct the invisible universe of mystical experiences. The dreamlike aspect of these landscapes was essential for transmitting a sensory state that transcended the bodily senses. For this reason, Jaime Mariazza Foy was quite right to consider that the landscape of viceregal painting provides a "[peculiar] vision of nature, a vision that conceptualized the notion of a utopian world, timeless and parallel to ours, created from elements of the real environment but destined to be a reflection of the pious spirit." (Mariazza Foy 2012, p. 50) (our translation).

Beyond the existing relationship in the 16th-century Flemish landscape between landscape paintings and the divine or the capacity of the landscape to become an exegetical tool, some Flemish painters used this way to visualize inner spiritual and mystical processes. In this part of the article, we will focus on some precise examples where the landscape was connected to the visionary painting as a concrete representation of the acquired contemplation. We are also interested in drawing attention to the compositional solutions that some Flemish painters adopted to insert the landscape into the narrative circuit of paintings, something that was recovered by viceregal painting, even becaming a compositional archetype in Cuzquenian painting. Although it is not a question of establishing a direct link or a linear influence between these models and the landscapes of viceregal painting, we must point out that the philosophical proposals concerning landscape painting as a materialization of inner spiritual processes, as well as certain compositional formulations that were also used in the Andes, are observed in several examples of European visual culture in the seventeenth century. There is no doubt that there are points of contact between them and that these contacts were mainly produced by the circulation of ideas. However, the transfer of ideas and models never follows a linear and clear direction, but rather becomes more complex, since it must pass through multiple sociocultural "translations".

Among the innumerable examples where we find the relationship between landscape and "vision", we highlight some representations of the theme of the biblical episode of the Gospel of Saint Luke in which Jesus visits the house of Martha and Mary in Bethany. This iconography is perfectly appropriate for the aims of this article, since, therein, the painters confront the issue of the representativeness of the contemplative state.

Beyond the different interpretations that the exegetes had of this biblical passage, from Origen (c. 184-c. 253) to the spiritual authors of the 16th and 17th centuries, the most widespread interpretation maintains that the figures of Martha and Mary personify the active life and the contemplative life, respectively. In general, authors ennobled Mary's behavior over Martha's; however, others preferred to see perfection in the form of balance between the two lives, which is the position of Saint Teresa de Avila (Lugo Bertrán 2017, pp. 146-47).

One of the challenges faced by painters depicting this subject was to find a visual formula that symbolized Mary's contemplative life. Until the beginning of the seventeenth century, they had resolved the issue by representing this character in a gesture of 
prayer, reclusion, and dedication to reading, holding a book in her hands-a symbol of doctrina doctas.

Around 1628, the Flemish painters Peter Paul Rubens (1577-1640) and Jan Brueghel II (1601-1678) produced a very novel representation of this scene for the Flemish painting of the 16th and early 17th centuries (National Gallery of Ireland, Dublin), a formal composition that had very little precedent. Unlike the usual indoor spaces that characterized the traditional composition of this scene, Rubens and Brueghel II transferred this biblical episode to the outdoors. Thus, a luminous landscape in the background (Van Mulders 2016, p. 94), attributed to the hand of Jan Brueghel II (Figure 1), frames the encounter of Jesus, Martha and Mary.

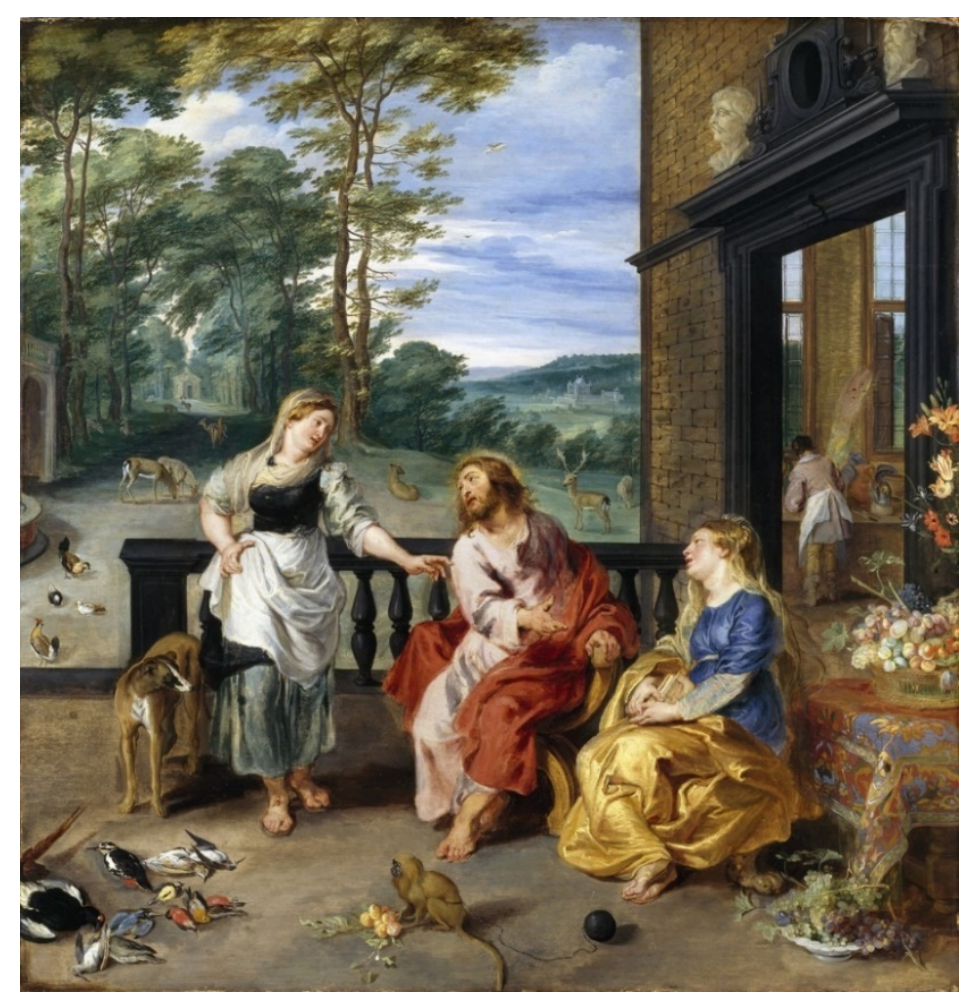

Figure 1. Peter Paul Rubens, Jan Brueghel II, Christ in the House of Martha and Mary, c. 1628, oil on oak panel, $64 \times 61.9 \mathrm{~cm}$. National Gallery of Ireland. Dublin Credit line: Wikimedia Commons.

In harmony with the symbolic and metaphorical tradition that the landscape possessed since the first Flemish landscape painters, such as Joachim Patinir (c. 1480-1524) or Herry Met de Bles (c. 1510-after 1550), Jan Brueghel the Elder (c. 1568-after 1625), the father of our painter, Brueghel II, associated this landscape with the metaphysical universe of the contemplative exercise personified in Mary. He established a parallel narrative between the landscape and other iconographic motifs that appear in the scene. While the contemplative life of Mary was represented by the landscape, in contrast, a group of carcasses of birds was related to the sterile exercise of the active life of Martha. Brueghel II also added some other motifs of nature that, as a doctrina serena, collaborated with the scene's interpretation. In this manner, he inserted in the landscape a group of deer, a well-known symbol of the penitent soul, which is also related to the ardent love for which the contemplative soul yearns (Hernández Miñano 2015, pp. 223-24). As Psalm 42-1-2 says: “As the deer pants for streams of water, so my soul pants for you, my God. My soul thirsts for God, for the living God. When can I go and meet with God?" The deer is contrasted with the representation of a chained ape, appearing at the lower part of the painting, which signifies, according to Christian tradition, the sin imprisoned by man, or, according to the activity of Martha, an image of the slothful soul (Eliade 1987, p. 65). 
The representation of Martha's and Mary's episode in the manner of Rubens and Brueghel II was widely reproduced by contemporary and later artists. Many of the copies and versions that were made of this painting intensified the role of the landscape as an iconographic motif, rather than a scenic background, intervening more directly in the narrative circuit of the painting. To accomplish this, the landscape was framed through compositional devices and visually linked to the representation of Mary, which is more evident than in the Dublin painting. For instance, in a canvas attributed to Vincent Malo (c. 1595-1649) executed around 1630-34 and preserved in the Rijskmuseum (Figure 2a), the painter depicted a landscape with a garden (a symbol of the Christian soul that was ready to be cultivated) between the figures of Christ and Mary, delimited by a vegetal frame. By proximity and by the gesture of Christ, the viewer should not have found it very difficult to associate this landscape with the character of Mary. On the other hand, Martha is linked with the food on the table on which she puts her hand.

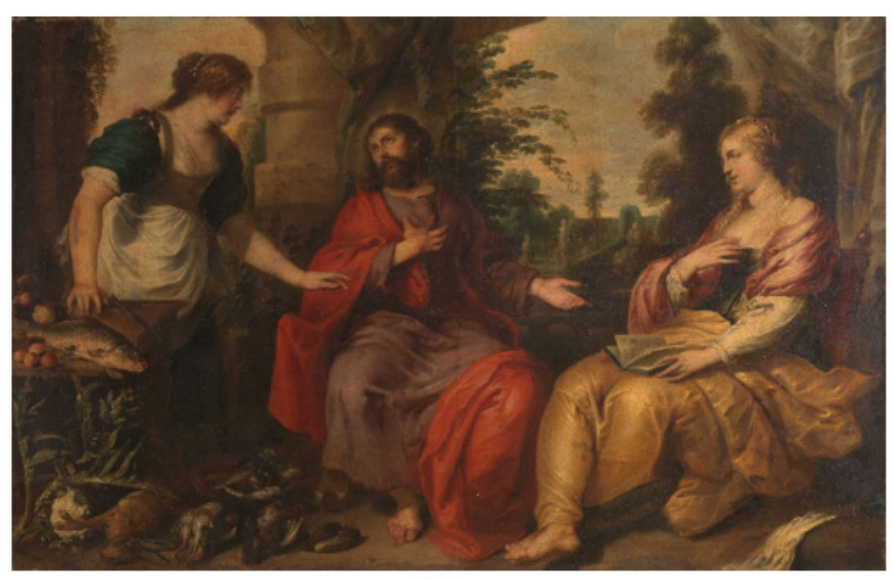

(a)

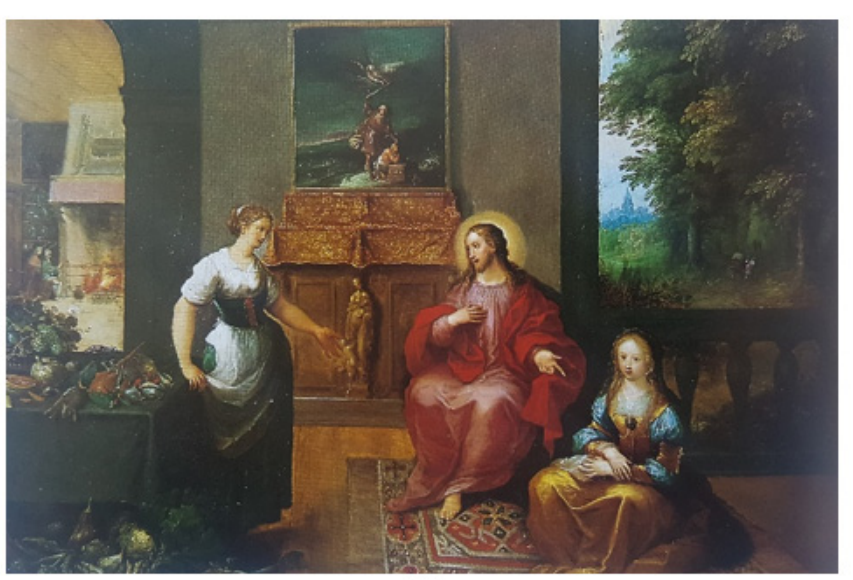

(b)

Figure 2. (a) Vincent Malò, Christ with Martha and Mary, c. $1630-$ c. 1634 , oil on canvas, $147.4 \times 230.5$ cm. Credit line: Rijksmuseum. (b) Frans Francken II, Christ with Martha and Mary, c. 1620, oil on panel, $57 \times 76 \mathrm{~cm}$. Private collection. Credit line: Härting, Ursula Alice. Frans Francken der Jüngere (1581-1642): die Gemälde mit kritischem Oeuvrekatalog. 1989.

Numerous small-format versions of this theme emerged from the workshops of Flemish painters, such as Frans Francken II (1581-1642) or Erasmus II Quellin (1607-1678), thereby demonstrating the great popularity of this compositional model. In these paintings, the narrative character of the landscape and its metaphorical function as an image of contemplative life were further emphasized. This is depicted more clearly in a panel executed by Frans Francken II himself, kept in a private collection (Figure 2b) published by Ursula Härting in $1989^{18}$. We are particularly interested in this model, since, from a formal point of view, it coincides with the compositional type used in the Andes when the landscapes were inserted into religious painting scenes taking place in indoor spaces. In this case, the composition maintained a much more linear narrative from left to right, linking the table again with the figure of Martha and the landscape that appears from a large window with a balustrade to Mary. Likewise, the painter represented in a landscape of lush greenery a group of characters entering a dense forest, a symbolic image of the peregrinatio vitae ${ }^{19}$.

It is quite suggestive that the formal and iconographic changes in the representation of the subjects of Martha and Mary took place at a time of doctrinal disputes in Northern Europe produced by the advance of the Flemish Perfectists and the Theologia Germanica. Carmelites accuse these doctrines of neglecting the inner exercises and the contemplation acquired through creatures to reach divine union. According to the Carmelite Jerónimo Gracián, who arrived in Flanders in 1609 , one of the mistakes made by Perfectism was to believe that: 
The meditation, and the knowledge of God through his creatures, and all the exercises of the inner and outer senses, and all the intellectual operations of the soul, and all other sensible and intelligible things are imperfect [ ... ] And that Mother Teresa of Jesus has not yet reached the greatest perfection: because she says in his books that God must be sought by his creatures, who lack the humility to want to become Mary, before having worked with Martha [ ... ]. (Gracián 1616, p. 211v) (our translation)

Precisely, we find another good example of using the landscape as a visionary experience representation in the work of another mystic Carmelite, the Portuguese father Joseph del Espiritu Santo. That can be seen in the engraving that preceded his mystical theology book, The Cadena Mystica Carmelitana (1678) (Figure 3. In this treatise, Joseph del Espíritu Santo explains the different types of contemplation (infused and acquired) and dedicates a good part of the book to arguing in favor of contemplation through creatures. All of these elements are depicted in the engraving with a similar symbolic framework to the one we have observed so far. The artist represented Father Joseph inside his cell experiencing a vision of Saint Teresa and Saint John of the Cross, who seemed to inspire him in the task of writing the Cadena Mystica. At the center of the composition, there is a representation of the dove of the Holy Spirit, which alludes to the devotional name of Father Joseph when he took up the habits of the order. In the background, there is an opening that framed a landscape, as a symbolic representation of acquired contemplation and the state of spiritual revelations that led the friar to the vision. The artist used a compositional model that, according to all evidence, had already proven acceptance: the inclusion of the landscape through vertical openings that produced a marked contrast between interior and exterior, darkness and light, confinement and immensity, and meditation and revelation.

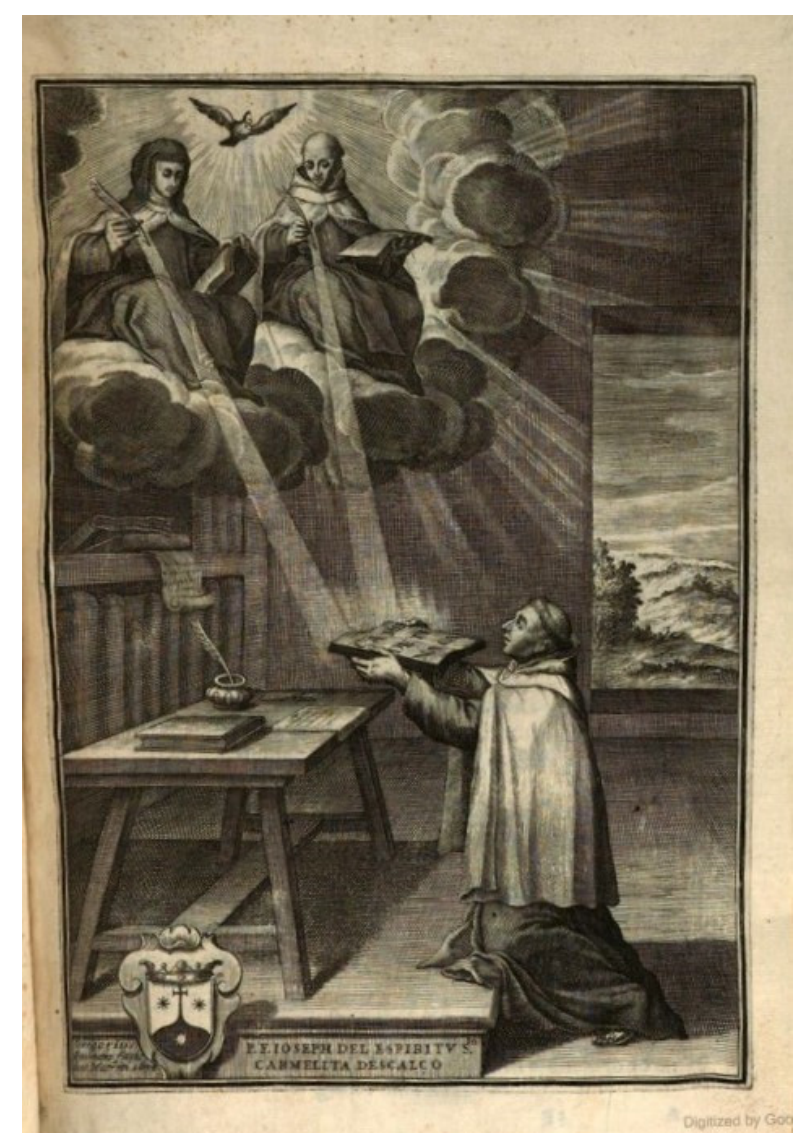

Figure 3. Unidentified artist, Joseph del Espiritu Santo receives a vision of Saint Teresa and Saint John of the Cross, 1678, In Joseph del Espiritu Santo, Cadena Mystica Carmelitana. Credit line: Digitized by Google Books. 
These examples discussed here serve to understand the rhetorical framework that exists behind the use of landscapes in certain compositional contexts. This framework helps us to identify conceptual and formal models that were certainly used by viceregal painters as an effective form in order to manifest their colonial spiritual experiences. Furthermore, it exposes compositional models that have to do with the ways of including landscapes within scenes in indoor spaces, which became very popular in Andean colonial painting.

\section{Landscape as Visionary Painting in Peru}

Although landscape painting in Peru was related to spiritual ideas based on contemplative exercises, there were different approaches and ways of applying these ideas according to the compositional context and the destination given to these landscapes. One of them was to consider the landscape as a tool that helped the retreatant with their spiritual meditations. It was recommended to have landscape paintings in rooms in order to observe them with Christian zeal and allow oneself to be transported in deep meditation. Cardinal Federico Borromeo, a great collector of landscape and still life paintings, expressed the benefit that could be drawn from these genres:

[ ... ] I have had my room ornamented with paintings, and I have made sure that all of them are excellent; there is not one vulgar or cheap thing. And the pleasure I take in looking at these painted views has always seemed to me as beautiful as open and wide views [of nature]. Instead of them, when they are not had, paintings enclose in narrow places, the space of earth and the heavens, and we go wandering, and making long [spiritual] journeys standing still in our room $[\ldots]^{20}$

Considering Cardinal Borromeo's advice, the significant quantity of landscape paintings, whether they are engravings, canvases, or paintings on copper plates, found in the inventories of the assets that belonged to the clergy in Peru is not surprising. As an example of this, we mention the inventory of Bishop Manuel Mollinedo y Angulo (1626-1699), who possessed within his great pictorial collection "a small hunt landscape, a picture of a landscape without frames [... ], two landscapes two yardsticks high, six fruit landscapes" (Mesa and Gisbert 1982, p. 289), or the inventory of the elected bishop of Chile, Luis Francisco Romero (Ob. 1705-1717), which showed "a hunting landscape, six fruit landscapes, and a field landscape measuring two yardsticks long and one yardstick (vara) and a quarter wide." Another example is the inventory of the cleric Juan López de Vozmediano (d. 1632), who had a total of "six landscapes" and "twelve small landscapes of groves without moldings or frames." (p. 289). Even more significantly, it was the number of landscapes owned by Francisco González de Zambrana (priest of the church of Chinchaipuquio, Cuzco) that almost tripled the canvases of religious paintings. The inventory, therefore, shows a number of "fifteen landscapes" in the priest's possession (AAC, Inventarios de iglesias, XXX, 1, 6, 1674).

The use of landscape painting to stimulate contemplative exercise explains that many recoletos convents, as propitious spaces for religious-secular spirituality and good breeding grounds for colonial mysticism, were decorated with extensive series of hermits and anchorites $^{21}$. The paintings of anchorites acted as a contemplative example for the pious exercise of the novices, since they inspired the spiritual benefits obtained from immersion between nature and its creatures, inciting a life of acute retreat.

In these paintings, the landscape occupied a decisive space in the composition, even becoming the most important element. This is observed in the series of the Recoleta Convent in the city of Sucre, whereupon painters privileged elongated frames in order to grant the landscape a more prominent space (Figure 4). This series used the engravings published by Thomas de Leu (1571-1611-12) in Paris as a model to illustrate The Sylvae Sacrae Monumenta Anachoretarum after an engraving by Johan Sadeler I (1550-1600) and design by Maarten de Vos (1532-1603) ${ }^{22}$. The painter of the Sucre series restricted the characters of the prints to the margins of the canvases, giving the landscape the leading role of the scene. It even seems that the anchorites functioned as figures of invitations or admonitors, since they invite the viewer to enter the main subject of the composition, the world theater, a space to 
contemplate God. A similar treatment is observed in other Cuzco series from the 17th and 18th centuries (Estabridis 1989)23.

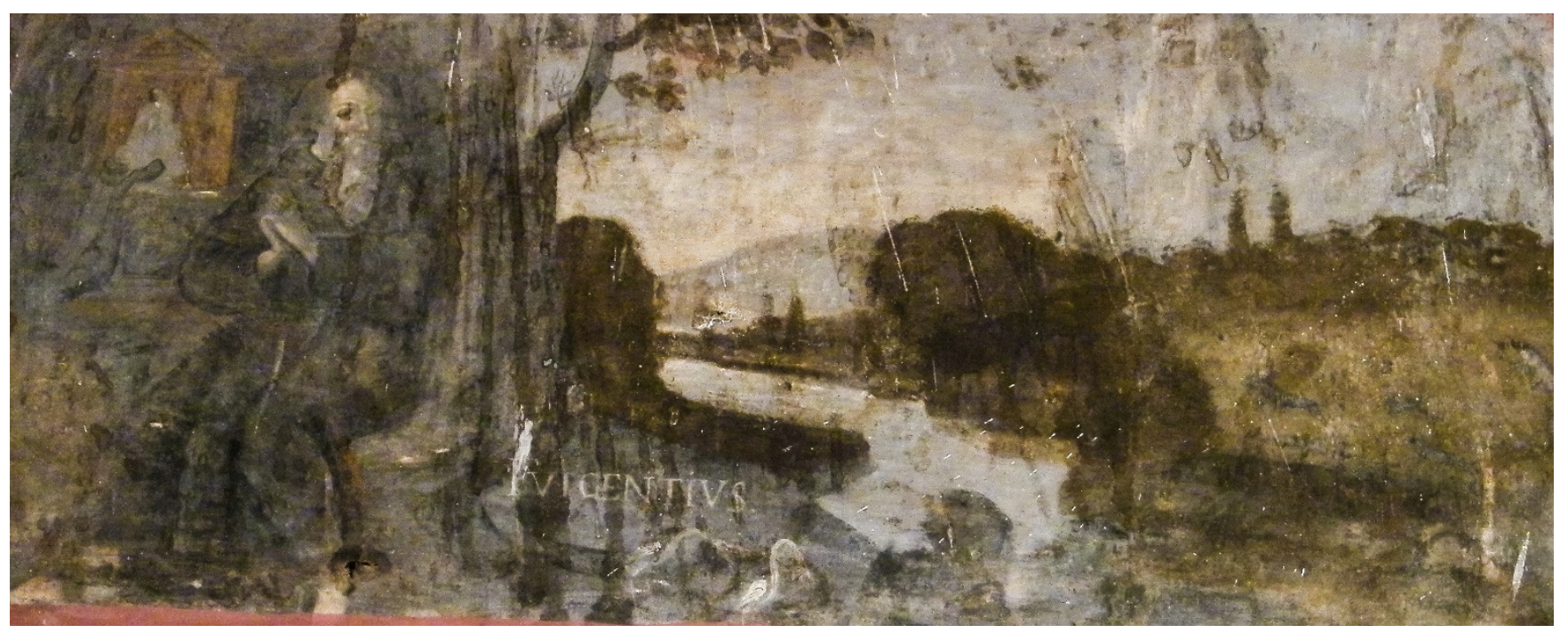

Figure 4. Unidentified artist, Fulgentius, Series of Anchorites, 17th century, oil on canvas, Convento de la Recoleta, Sucre, Bolivia. Credit line: Sebastian Ferrero.

To help in spiritual meditations, landscape painting in convents was agreed by other devices, such as the cloister gardens or floreros. They were the gateway to a universe of deep meditation. For this reason, in his most famous book, the asceticism treatise entitled El Pastor de la Noche Buena (1643) (Zugasti 2000, pp. 297-99), Juan de Palafox, bishop of Puebla (Mexico) between 1640 and 1650, describes the palace of disenchantment visited by the pastor during its rapture as an ideal convent decorated with landscape paintings and arrangements of flowers and plants in the cloister garden. These elements kept the inhabitants of this convent, spiritual exercisers, in a state of a deep trance that surprises the shepherd (pastor), who is, in turn, immersed in a visionary rapture accompanied by an angel (Palafox y Mendoza 1662, pp. 32-33).

In these cases, the landscapes could condense the vast universe of liber naturae into an image, needing only the contemplative gaze of the viewer to activate it. The connection of the landscape to the idea of the book of nature certainly inspired the painter of a series depicting the life of Saint Ignatius that was commissioned in the second half of the seventeenth century (probably between 1670 and 1680 due to the presence of floral borders) by the Jesuit Fathers of the city of Juli. Among the different episodes of this series, we emphasize one of the most emblematic moments in the life of Saint Ignatius: the composing of the Exercises in the city of Manresa (Figure 5a). For the representation of this canvas, the painter used an engraving executed by Jean Baptiste Barbé (1578-1649) and published in the edition of the Vita beati P. Ignatii Loyolae, Societatis Jesu fundatoris of $1609^{24}$ (Figure 5b). The composition is similar to that of the series of anchorites with a strong horizontal treatment of the scene, although the landscape takes greater preponderance than it had in the original engraving. The painter of this canvas sought to highlight the importance that the contemplation of nature had for Saint Ignatius in the Exercises, and probably had in mind a passage from the "Contemplation to Gain Love", where Saint Ignatius suggests to the exercitant:

[ ... ] to consider how God dwells in creatures, in the elements, giving them existence; in the plants vegetating, in the animals feeling in them, in men giving them to understand: and so in me, giving me being, animating me, giving me sensation and making me to understand; likewise making a temple of me, being created to the likeness and image of His Divine Majesty; reflecting as much on 
myself in the way which is said in the first Point, or in another which I feel to be better. In the same manner will be done on each Point which follows.

[ ... ] to consider how God works and labors for me in all things created on the face of the earth—that is, behaves like one who labors-as in the heavens, elements, plants, fruits, cattle, etc., giving them being, preserving them, giving them vegetation and sensation, etc.

[... ] to look how all the good things and gifts descend from above, as my poor power from the supreme and infinite power from above; and so justice, goodness, pity, mercy, etc.; as from the sun descend the rays, from the fountain the waters, etc. ${ }^{25}$

Saint Ignatius reduces his vision of the natural world, the world to be contemplated, to a series of elements, such as sunlight, flowers, plants, rivers, and fountains, all of which formed a kind of reduced model of liber naturae that we can commonly find in a typical landscape painting. In other words, the vision of Saint Ignatius does not differ much from the way that Flemish painters built their Weltlandschaft. This is why Cardinal Borromeo said that Flemish panoramic views "enclose in narrow places, the space of earth and the heavens, and we go wandering, and making long [spiritual] journeys standing still in our $\operatorname{room}[\ldots] . "$

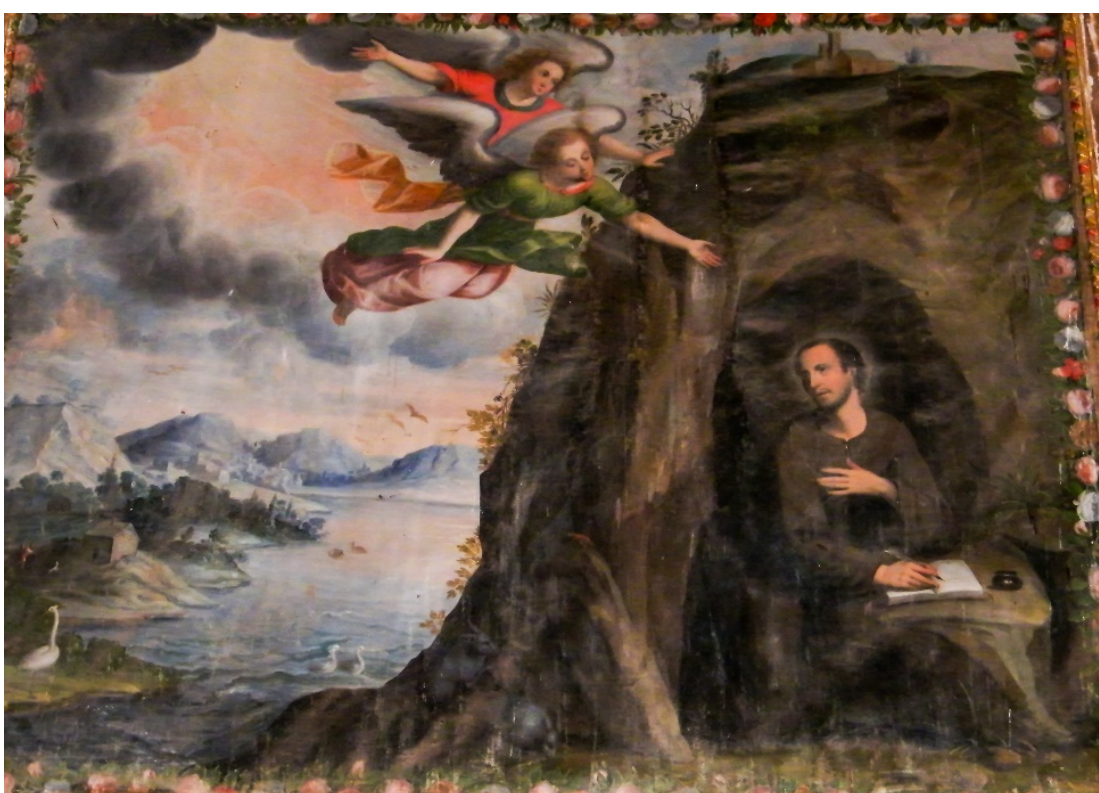

(a)

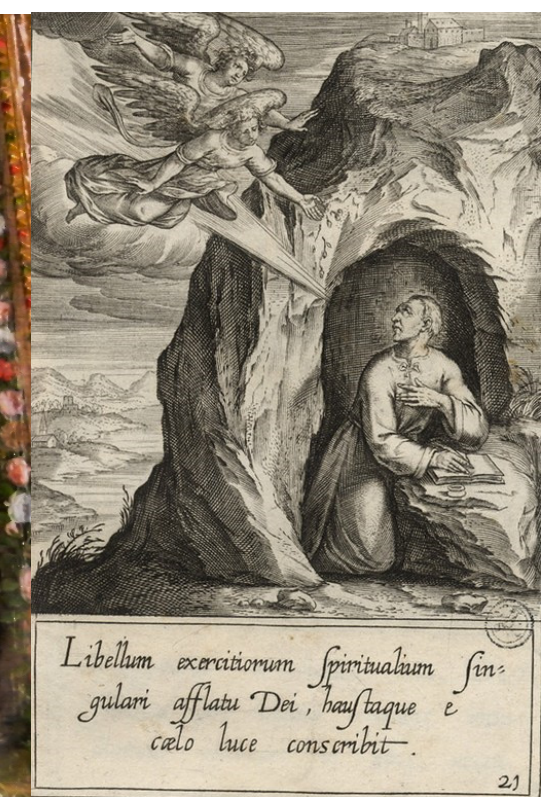

(b)

Figure 5. (a) Unidentified Cuzco artist, Saint Ignatius Composes the Spiritual Exercises at Manresa, 17th century, oil on canvas, Iglesia de San Pedro, Juli, Puno, Peru. Credit line: Sebastian Ferrero (b) Jean Baptiste Barbé, Saint Ignatius Composes the Spiritual Exercises at Manresa, 1609, etching and engraving, Plate 21 of the Vita beati P. Ignatii Loyolae, Societatis Jesu fundatoris, with Latin texts by N. Lancicius. Credit line: Portugal National Library from PESSCA (Project on the Engraved Sources of Spanish Colonial Art).

In addition to the main aspect of the landscape, the painter of this canvas made another modification to the original engraving: the key to interpreting the meaning of the painting. If we draw a vertical axis from the two angels that appear to inspire the Jesuit in the written task in Barbé's engraving, we find, at the bottom of the canvas, the representation of two vizcachas, endemic animals of the Andes, that replicate the angels in number and location in the composition. The presence of these two Andean animals is not a folkloric addition or a simple regionalism, but rather, they communicate to the viewer that the true revelation of San Ignacio came from the inquiry of nature. For this purpose, the painter appeals to the Andean mythical meaning of the vizcachas, 
considered by the Andean communities as messengers of the mountains (mules of the Apus) (Flores Ochoa et al. 1993, pp. 190-91; Macera and Evanán 1999, pp. 25, 48; Esteras Martín 2004). By representing the vizcachas on the same vertical axis as the angels, he sought to compare these two beings in their nature as divine messengers. Unlike Barbé's engraving, Saint Ignatius overlooks the presence of angels and adopts a much more contemplative gaze, directed slightly towards the sector that occupies the landscape, a vital source for reaching divine knowledge and love.

As in Juli's canvas, the theme of nature as God's second book was represented by some other viceregal painters in various compositions. Among them was the famous Cochabamba painter Melchor Pérez de Holguín (ca. 1665-ca. 1730), a renowned painter of ascetic and mystical subjects. In the series of the four evangelists executed in 1714 and preserved in the Museo Nacional de Arte of La Paz (Figure 6a-c), Holguín displayed a kind of moral theater and a series of battles between good and evil fought by different animals. If we compare the painting of Saint John Evangelist with the model used by Holguín, an engraving by François de Poilly (1623-1693) after a painting by Charles Le Brun (1619$1690)^{26}$ (Figure 6d), we realize the interest of the Cochabamba painter in the representation of the landscape, which is much more developed and detailed than the appearance in the de Polly's engraving. Likewise, Holguín, conceives the landscape as a frame where the mysteries of God revealed through the behavior of nature. These animalistic scenes replaced the conventional iconographic motifs that generally appeared in other series of the four evangelists, which used different episodes taken from the gospels represented at the bottom of the composition ${ }^{27}$. In this way, the painter visualized the two channels through which the Word manifested itself, that is, the two books: the gospels and the book of nature.

In another canvas of Juli's series of Saint Ignatius's life, the painter once again modified the original engraving in order to suggest the metaphysical aspect of this episode. This canvas represents a visionary chapter in the life of Saint Ignatius, the appearance of Saint Peter after Ignatius had suffered a wound during the protection of the castle of Pamplona in 1521 (Figure 7a). Contrary to the extrospective role played by nature in the first canvas, the one of Saint Peter Appears to Saint Ignatius shows the capacity of the landscape to visualize introspective spiritual processes. The artist used an engraving by Theodor Galle (1566-1638) that was executed in 1610 for the Vita Beati Patri Ignatii Loyolae, Religionis Societatis Iesu Fundatoris by Father Pedro de Ribadeneyra ${ }^{28}$ (Figure $7 \mathrm{~b}$ ). The print is a composition of three episodes of Saint Ignatius's life: The Appearance of Saint Peter is the scene of the foreground, and there are another two in the background, a temptation of the devil, whom Saint Ignatius faces through prayer, as well as through a vision of the Virgin and the child. The painter, most likely from Cuzco, replaced these scenes with a window that revealed a distant landscape with an orthogonal garden in the front. The visionary aspect of the background scenes found in the engraving is now assumed by the landscape, representing the soul of Saint Ignatius as a garden ready to be cultivated with a divine revelation ${ }^{29}$. Access to the soul through windows derives from the widespread metaphorical construction of the senses as the doors and windows into the soul.

The landscape as a visualization of introspective exercises was used in other iconographic contexts of saints and retreatants who experienced long spiritual trances. A good example of this is the paintings that represented different events in the life of the Spanish mystic Santa Teresa de Avila, known for her long stays in the "moradas del alma". It is very common to find in colonial painting the representation of landscapes accompanying Teresa's spiritual path. It is not surprising, therefore, that many of the engravings depicting Teresa's mystical life in her cell have been modified by viceregal painters with these elements. 
(a)
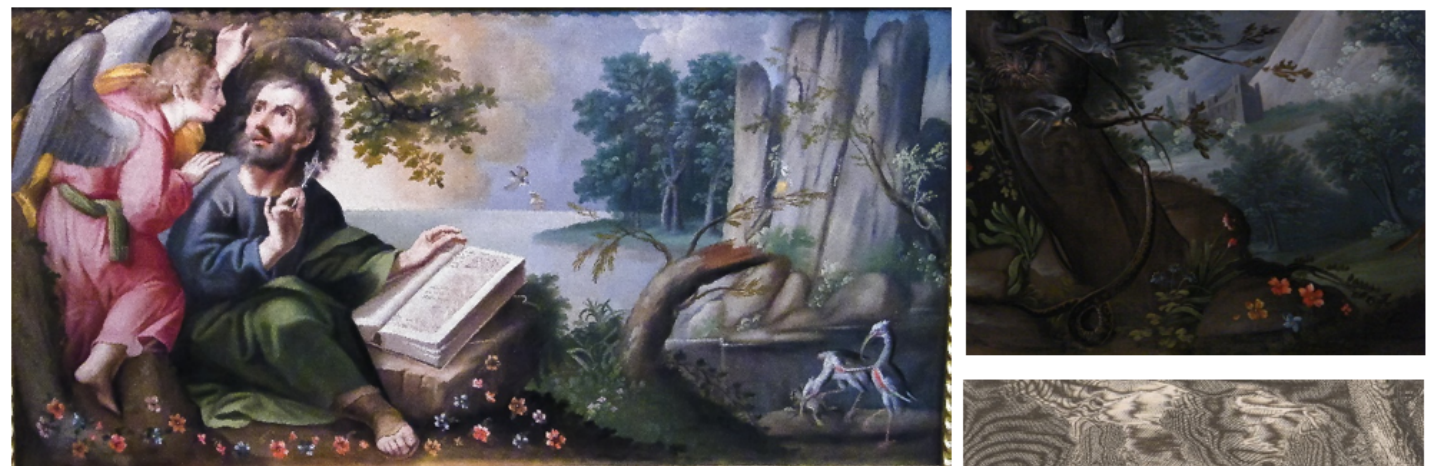

(b)

(c)


(d)

Figure 6. (a) Melchor Pérez de Holguín (ca. 1665-ca. 1730). Saint Mark the Evangelist, 1714, oil on canvas, Museo Nacional de Arte, La Paz, Bolivia. Credit line: Sebastian Ferrero. (b) Melchor Pérez de Holguín (ca. 1665-ca. 1730). Saint Luke the Evangelist, detail, 1714, oil on canvas, Museo Nacional de Arte, La Paz, Bolivia. Credit line: Sebastian Ferrero. (c) Melchor Pérez de Holguín (ca. 1665-ca. 1730). Saint John the Evangelist, 1714, oil on canvas, Museo Nacional de Arte, La Paz, Bolivia Credit line: Sebastian Ferrero. (d) François de Poilly after Charles Le Brun, Saint John the Evangelist at Patmos, 1657-1681, engraving, $442 \mathrm{~mm} \times$ width $327 \mathrm{~mm}$, credit line: Rijksmuseum, public domain.

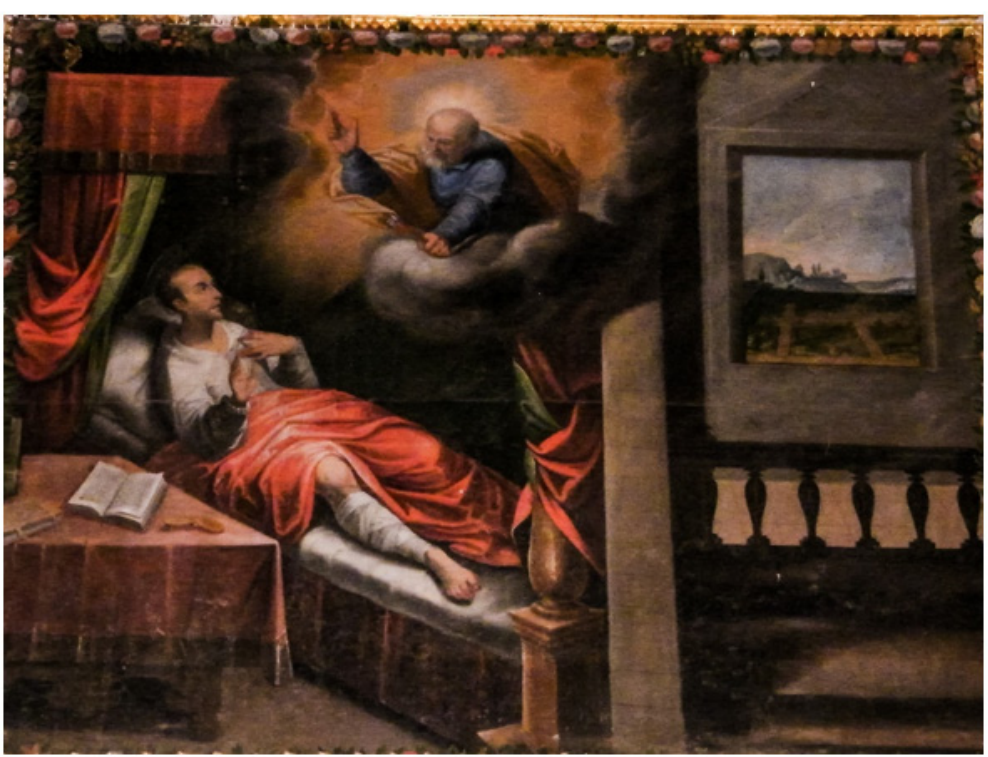

(a)

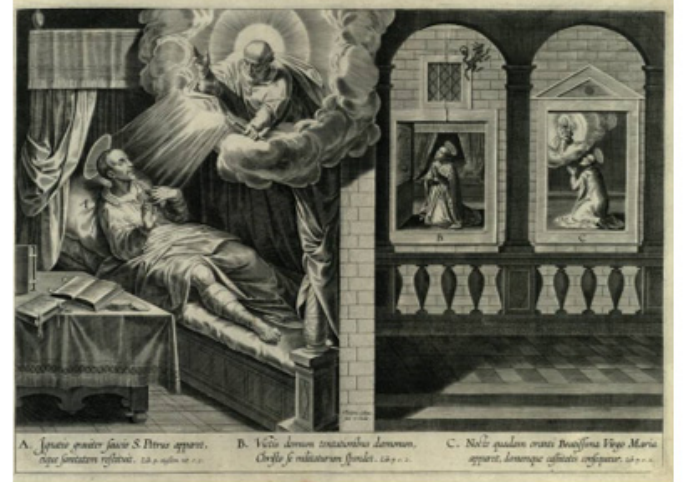

(b)

Figure 7. (a) Unidentified Cuzco artist, Saint Peter Appears to Saint Ignatius, 17th century, oil on canvas, Iglesia de San Pedro, Juli, Puno, Peru. Credit line: Sebastian Ferrero. (b) Theodor Galle (1566-1638), Saint Peter Appears to Saint Ignatius. Ignatius resists temptation through prayer. The Virgin Mary and the child appear to Saint Ignatius, 1610, engraving. In Pedro de Rivadeneira, S.J., Vita Beati Patri Ignatii Loyolae, Religionis Societatis Iesu Fundatoris. Credit line: Boston College Libraries from PESSCA (Project on the Engraved Sources of Spanish Colonial Art). 
This communion between Teresa's spiritual exercises and the landscape were opportunely denoted by the Spanish writer and essayist Miguel de Unamuno. In his essay "Paisajes teresianos", Unumuno presented the contemplative process of Santa Teresa in Becedas as spiritual exercises consisted of variations between reading the sacred texts and contemplating the landscape. In other words, she alternated between logos and liber naturae. This kind of contemplative activity helped her to contemplate "the field" as a metaphor for the invisible world (Unamuno 1922, p. 247). For this reason, Miguel de Unamuno concluded that, for Santa Teresa, "The visible universe is a metaphor for the invisible, the soul" (p. 250).

The idea of the landscape as a metaphor for the soul was manifest in various compositions of ecstatic episodes of Santa Teresa. In line with this intention, the viceregal painters transformed the engravings from Europe with landscapes that appeared inside modest interior spaces where the saint of Avila was consecrated to her spiritual exercises.

For instance, on an 18th-century canvas conserved in the convent of Santa Teresa de Arequipa, depicting the Transverberation of Saint Teresa (Figure 8a) an engraving by Anton Wierix (1555-1604) ${ }^{30}$ (Figure $8 \mathrm{~b}$ ), the Andean artist reduced the visionary motifs of the print with a modest diaphanous light in the upper part of the canvas and included an idyllic landscape with water birds represented in pairs (symbol of the divine union), which can be seen through a window in the background of the space. The same recourse was used by another unknown painter on a canvas that is preserved in the Museo de Arte de Lima (MALI), which is dated between 1700 and $1730^{31}$. On this occasion, it is an Illumination of Saint Teresa that employed an engraving by Adriaen Collaert (1555-1623) and Cornelis Galle I (1576-1650) (Penhos 2015, p. 106) as a visual model. The landscape did not appear in the original engraving, so the viceregal painter added it in the windows of the background, which were crossed by the dove of the Holy Spirit, the origin of the wisdom of Saint Teresa's soul, holding a phylactery saying: "Spiritu intelligentiae repleuitillam." The idea of the window through which we contemplate the soul was used once again.

In addition to windows, another way to include landscapes in these interior scenes is the vertical opening at the back of the space, and this was probably the form most used by viceregal painters. As we have previously appreciated, this compositional model was imported from Europe, but generally, it was never directly copied from an engraving. Likewise, this compositional use took on much more important proportions in viceregal painting than in European painting. The landscapes included in a viceregal painting were rarely present in the original engraving. The contrast between the shady interior spaces and the luminous landscapes produced by this kind of compositional device allowed the viewer to visualize the transition made by the exerciser from the sensitive to the suprasensible.

In this regard, the viceregal counterparts of these Teresian models are the representations of the life of Santa Rosa de Lima. Many scenes of penance, prayer, and, above all, Rosa's mystical marriage, where the landscape translates the moment of full enjoyment and the natural context that characterizes the mystic union between the loved and the Beloved, were composed through this process of transforming the engravings with landscape and garden motifs (Figure 9).

The penances and spiritual exercises of Saint Rose constantly led her from the earthly world to the spiritual world. One of her biographers, the German Dominican Leonardo Hansen, described how she, during the embroidery exercise, would enter in and out of ecstasy in each of the stitches she made. According to Hansen, when Rosa was sewing and when she raised her needle and thread high, it seemed that she lifted her spirit in divine ecstasy; and being briefly suspended in space, with her hand still raised, she would return at the same moment to the work, with such successful skill and with such dexterity, that the needle would be turned to the exact place so that the work would be finished (Mujica Pinilla 2005, pp. 235-37). 




(a)

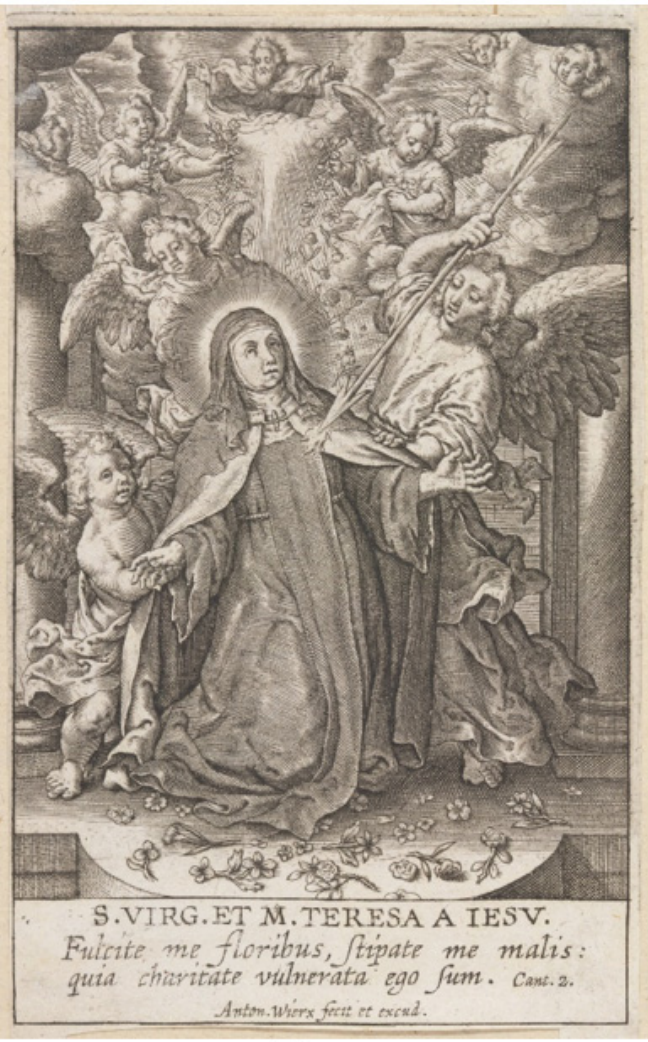

(b)

Figure 8. (a) Unidentified artist, Transverberation of Saint Teresa, 18th century, oil on canvas, Monasterio de Santa Teresa, Arequipa, Perú. Credit line: Sebastian Ferrero. (b) Anton Wierix, The Transverberation of St. Teresa, engraving. Credit line: The Metropolitan Museum, New York.



Figure 9. Unidentified artist, Mystic Nuptials of Saint Rose of Lima, 18th century, oil on canvas. Monasterio de Santa Rosa, Lima. 
This scene was represented on multiple occasions by viceregal painters after an engraving by Cornelis Galle II (1615-1678), which was executed for the Vita et Historia S. Rosae (c. 1672) (Figure 10b). In order to suggest the visionary state of Rose, Galle II limited himself to the representation of the infant Jesus, who often appeared and accompanied his wife in her daily tasks (Page 2009, p. 37). For many viceregal painters, this way of visualizing the Saint Rose trance was not sufficiently representative, and so they decided to go to the landscape to reformulate the ethereal world of ecstasy. As an example of that, we mention a painting preserved in the collection of Carl and Marilyn Thoma, which was executed in the 18th century (Figure 10a). In this case, the landscape also served as a mystical setting in which Saint Rose traveled the path of perfection. To imply this transit of the soul, the painter represented other episodes of Rosa's Life within the landscape, which were also taken from two Cornelis Galle II engravings from the same series: the attack of the demon in the form of a dog, Demonum Vixtrix, and Saint Rose penitent, Severa in corpus (Figure 10c). On this last engraving, we distinguish a seventeenth-century Cuzco painting that also opened the background of the composition with a landscape of trees and a few songbirds ${ }^{32}$, a space accessed by Saint Rose through the penance and mortifications of her body $^{33}$ (Figure 10d).

The use of this compositional device in which luminous and idyllic landscapes were a counterpoint to gloomy interior spaces would be useful, in turn, to communicate to the viewer the spiritual benefits derived from the life of monastic seclusion. Meditation, prayer, and penance opened the door to experiencing a joy comparable to idyllic, flowered, and colorful valleys. Therefore, Joseph del Espíritu Santo called Saint Teresa and Saint John of the Cross "anchorites of the cities" (Joseph del Espíritu 1678). The Creole Jesuit Balthasar de Moncada (1683-1768) considered that the spiritual retreat in the deep silence of the Casa de Recolección de la Compañia at Lima mentally transported the retreatants to an open countryside (Moncada 1757, Prologue). Another Creole Jesuit, Jacinto Morán de Butrón (1668-1749), biographer of Mariana de Jesús, better known as La Azucena de Quito, described the many-day confinements of Mariana in her cell as a stay in the forest (Morán de Butrón 1702, p. 5). The same can be said of the minor Franciscan Fray Juan de Peralta who, according to his biographer Joaquín Gomez, "found in the narrow Cloisters of the Anchorite Convent long deserts of loneliness" (Gómez 1749, p. xxvii r). In this context, painting landscapes were meant to visualize an ethereal world that appeared supernaturally through the complete dissolution of the limits of conventual confinement. All of this was achieved through the training of the soul's potencies during the purgative path.

Just as the human body imprisoned the soul, the cell walls contained an immeasurable nature that was accessible through meditation, prayer, or penance. The pictorial representation of this metaphysical phenomenon, in which the body of the practitioner is transferred from one space to another-from the convent to immeasurable countryside-is evident in compositions of great originality. In this regard, we note a canvas conserved in the monastery of Santa Catalina of Cuzco, a 17th-century painting according to Pedro Gjurinovic Canevaro (2012, pp. 142-43), which represents one of the best-known miracles of the Peruvian saint, San Martín de Porres (1579-1639): to make a dog, a cat, and a mouse eat from the same plate in complete harmony (Figure 11). The scene seems to be set in the garden of the conventual cloister of Santo Domingo de Lima, where San Martin entered in 1594 as a lay brother. In the foreground, Martin commands these animals to eat together from the same plate without quarreling, while a few Dominican brothers observe the miracle from the opposite arcades. The most interesting thing about this canvas is how the painter represents the seclusion and monastic retreat as a mental and spiritual journey that places the soul outside the conventual limits. Thus, we can see how one of the walls of the convent is artificially dissolved, allowing us to perceive a landscape that certainly has nothing to do with Lima's views, but rather presents as an image of a metaphysical and idealized world in Flemish landscape style. The place is inhabited by a shepherd and his sheep, which could be an allusion to the divine shepherd, the Beloved of the Song of Songs, remembering the final stage of the Unitive path. 




(a)

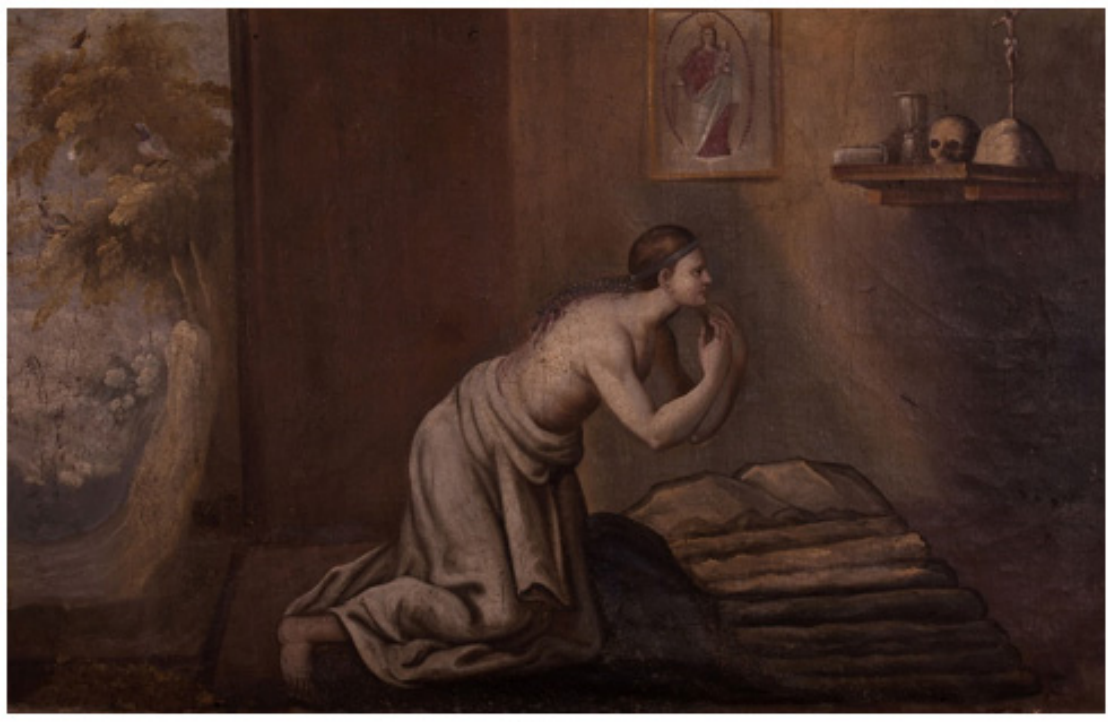

(c)

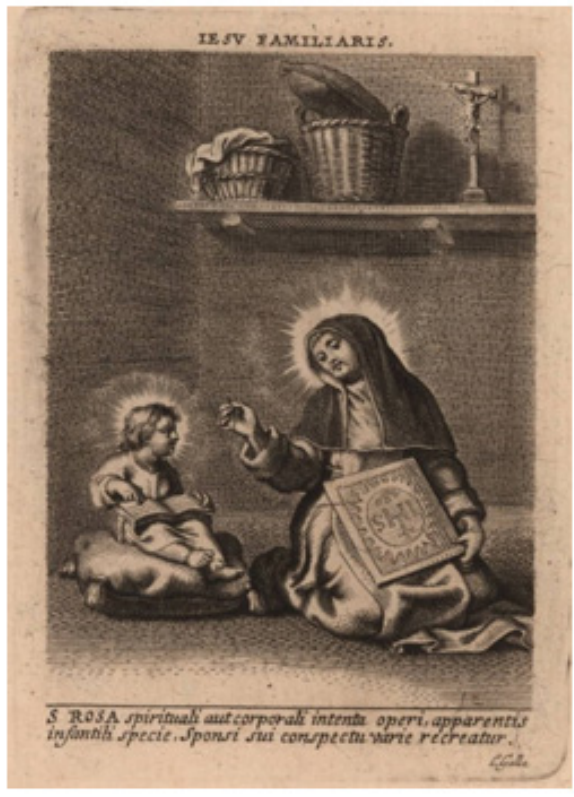

(b)

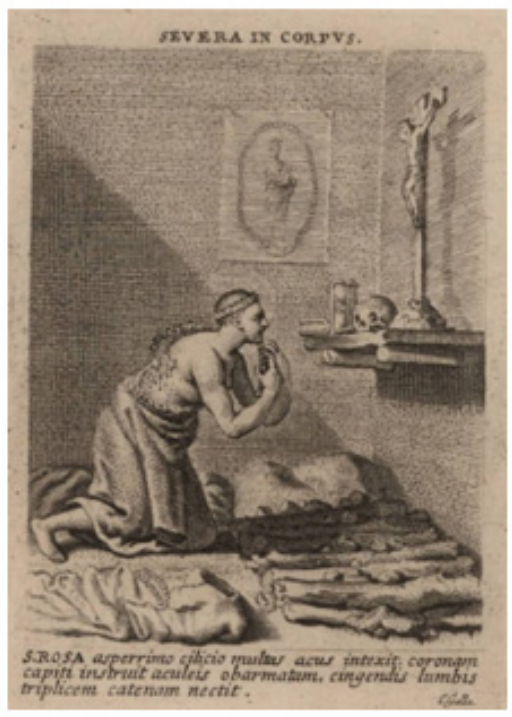

(d)

Figure 10. (a) Unidentified artist, Saint Rose sewing, 18th century, oil on canvas, Carl and Marilynn Thoma collection. Credit line: Thoma Foundation. (b) Cornelis Galle II (1615-1678), Iesu familiaris, c. 1672, engraving, in Series on the Life of Saint Rose of Lima. In Vita et Historia S. Rosae. Credit line: John Carter Brown Archive of Early American Images from PESSCA (Project on the Engraved Sources of Spanish Colonial Art). (c) Unidentified Cuzco artist, Severa in corpus, second half of the 17th century, oil on canvas, Monasterio de Santa Catalina de Siena, Arequipa, Peru. Credit line: PESSCA Archive. (d) Cornelis Galle II, Severa in corpus, c. 1672, engraving, in Series on the Life of Saint Rose of Lima. In Vita et Historia S. Rosae. Credit line: John Carter Brown Archive of Early American Images from PESSCA (Project on the Engraved Sources of Spanish Colonial Art). 




Figure 11. Unidentified artist, Saint Martin de Porres. Feeding dog, cat, and mouse miracle, 17th century, oil on canvas. Monasterio de Santa Catalina, Cuzco. Credit line: Pedro Gjurinovic Canevaro, Iconografía de San Martin de Porres, 2012.

Likewise, we find a series of four small canvases ${ }^{34}$, which are preserved in the convent of La Merced in the city of Cuzco and deal with the same topic. Despite containing figures and stories, we could consider them, from a compositional point of view, as landscape paintings. In all cases, a Mercedarian friar is represented performing a wonder, penance practices, or spiritual exercises. These characters are confined to a corner of the composition, leaving most of the canvas space to landscape painting. All are friars who served in the viceroyalty and died in the odor of sanctity while still having beatification or canonization processes open. Two of them are identified on the canvases by legends; they are the servants of God Fray Antonio de San Pedro, a converted Jew born in Celorico da Beira of the diocese of Guarda (Portugal), who would serve a sentence of three years in the convent of La Merced in the city of Lima, and Fray Gonzalo Díaz de Amarante, another Mercedarian from Portugal who also professed for fifteen years in the convent of La Merced in the same city. The canvas that represents Fray Antonio inflicting great pain on himself while lying naked in a garden of thorns is probably the best achievement of the four landscapes.

However, the most interesting canvas for this study has lost its legend, preventing us from properly identifying it. It would be another venerable Mercedarian father who, quite possibly, would have professed in Peru. This friar appears at the extreme left of the composition wearing the habit of the order. His gesture seems to indicate that he has fallen into a deep trance while he contemplates the crucifix (Figure 12). Despite finding similarities with the theme of the holy hermits, due to their representation in total immersion in nature, these paintings from the Mercedarian convent represented friars who served in viceregal convents in urban spaces. Therefore, the landscape here must be interpreted as the representation of the friar's mental transfers from the conventual cell to the imagined countryside. The confinement's transformation into immense spiritual freedom is assumed by an idyllic landscape painting. 


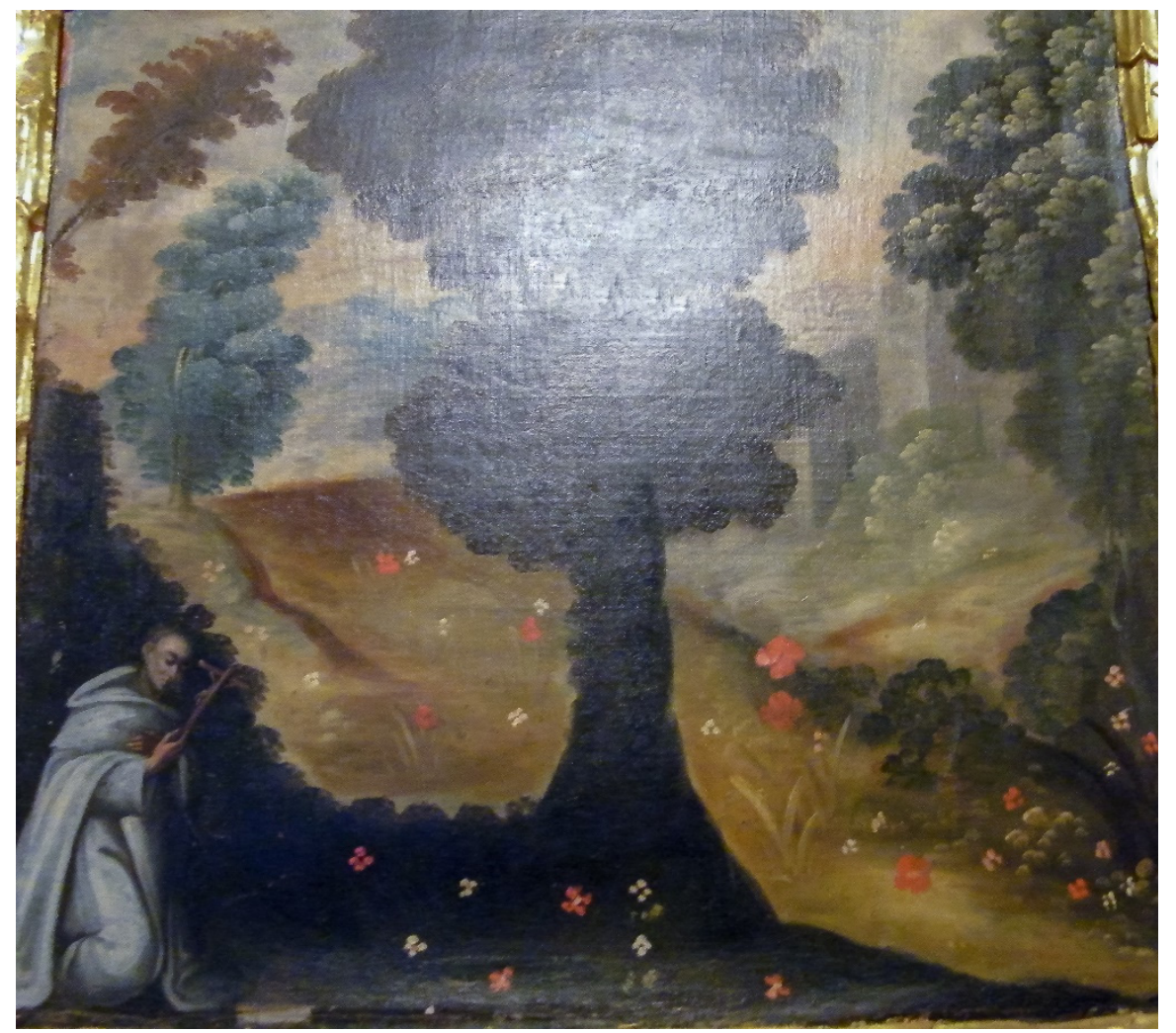

Figure 12. Unidentified artist, Contemplative Mercedarian Father, 18th century, oil on canvas. Convento de la Merced, Cuzco. Credit line: Sebastian Ferrero.

In another vein, a canvas preserved in the Museo de Arte de Lima (MALI) depicting the Dormancy of the Virgin, which was executed in the 18th century (Figure 13a), shows a very peculiar use of the landscape in colonial Andean painting. Here, the landscape played a much more complex narrative role, which even tackled a theological issue regarding the true nature of the assumption of the Virgin, either in soul or, on the contrary, in body and soul (Stoichita 1996, pp. 40-44). The composition follows a 1567 Cornelis Cort (ca. 1533-1578) engraving after a design by Federico Zuccaro (1542-1609) (PESSCA, $3865 \mathrm{~A})^{35}$ (Figure $12 \mathrm{~b}$ ), which was later transformed by the colonial painter. He eliminated the angels that, according to some apocryphal texts, such as Dormitionem BV Mariae of John of Damascene, veil the Virgin Mary on her deathbed and, three days later, accompany the transit of her body to Glory (González 2017). He added the presence of the dove of the Holy Spirit, which is absent in the original engraving. Finally, he integrated an exquisite twilight sky landscape on the right side of the canvas, taking up almost half of the composition. Luis Eduardo Wuffarden is right in pointing out the dislocated and unreal aspect of the scene that the insertion of the landscape gives, as it is also correct, in our opinion, to link the landscape with the assumed character of this episode (Wuffarden 2016, p. 116). According to John of Damascene, it was Jesus himself who descended to receive Mary's soul and led her to the celestial throne, and not the Holy Spirit. Consequently, the presence of the dove on the MALI canvas could have different interpretations: marking the beginning and the end through the conception and death of Mary, alluding to the role played by the Holy Spirit in warning the apostles of the death of the Virgin and then transporting them on clouds to the place where the Holy Mother lay; or, it could highlight the descent of the Holy Spirit to rescue the body of Mary and to take it to heaven and complete the anticipated resurrection of the Virgin in soul and body. 




(a)

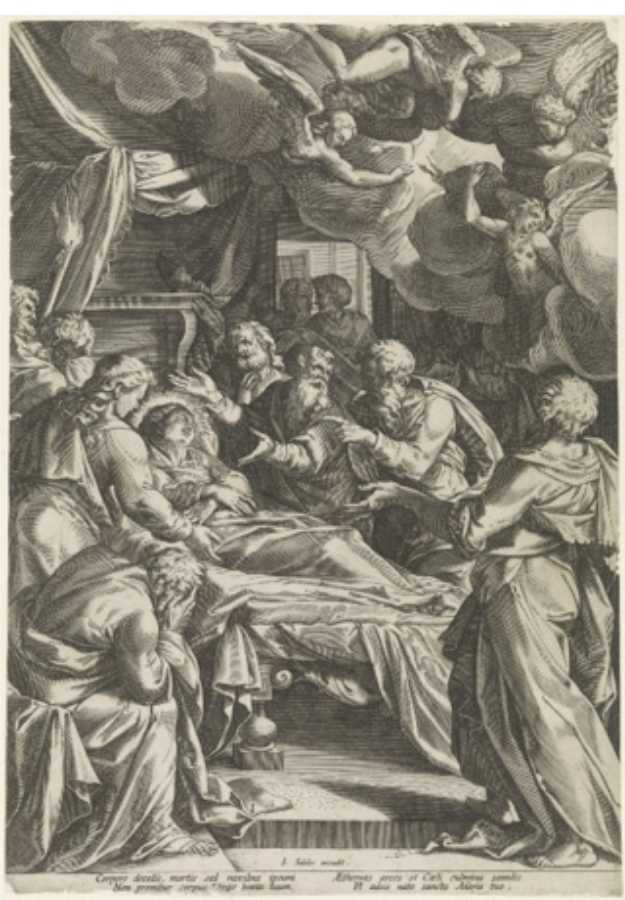

(b)

Figure 13. (a) Unidentified artist, The Dormancy of the Virgin, 1730-1770, oil on canvas, Museo de Arte de Lima (MALI), $131 \times 103$ com. Credit line: Wikimedia Commons. (b) Jan SadelerI (publisher and possibly engraver) after an engraving by Cornelis Cort and a design by Federico Zuccaro, The Dormancy of the Virgin, 1567-1600, engraving. Credit line: Rijksmuseum.

The Dormancy indicates the moment that Mary's soul ascends to Heaven., a difficult episode to depict. The painter solved these visualization problems in an allegorical manner by including a landscape that served as the narrative structure of the event. This element materializes the moment when the Virgin's soul went out to meet her Beloved, Jesus Christ. In addition to the supernal effect that the landscape spreads throughout the scene, some motifs added therein reveal the exact meaning of this landscape. In the distance, we observe a group of seven birds (probably doves) heading towards the twilight sun. This was an allegorical representation of the soul of Mary that went out to meet her Beloved, personified in the rising sun. The identification of the dove as a metaphorical figure of the soul comes from book 6 (9-10) of the Song of the Songs:
but my dove, my perfect one, is unique,
the only daughter of her mother,
the favorite of the one who bore her.
The young women saw her and called her blessed;
the queens and concubines praised her.
Who is this that appears like the dawn,
fair as the moon, bright as the sun,
majestic as the stars in procession?

The number seven symbolizes the stages that the soul has to travel on the path to perfection. In the mystical exercises of Saint Teresa, these stages are represented as the seven dwelling places, and in the case of the Virgin, they could refer to the seven joys. In this sense, it is interesting to consider one of the emblems from Antonio González de Reyes's book, Representaciones de la verdad vestida, misticas, morales, y alegoricas sobre las Siete Moradas de Santa Teresa de Iesús, published in 1677 (Figure 14). This engraving begins the book and shows the process of the union between the soul and its beloved through seven steps, depicting as seven dwellings of the castle. Logically, the engraver symbolizes the soul 
as a dove flying towards her Beloved, depicted in turn as the Sun. In other words, the landscape represents the important moment in which Mary's soul rises to heaven.

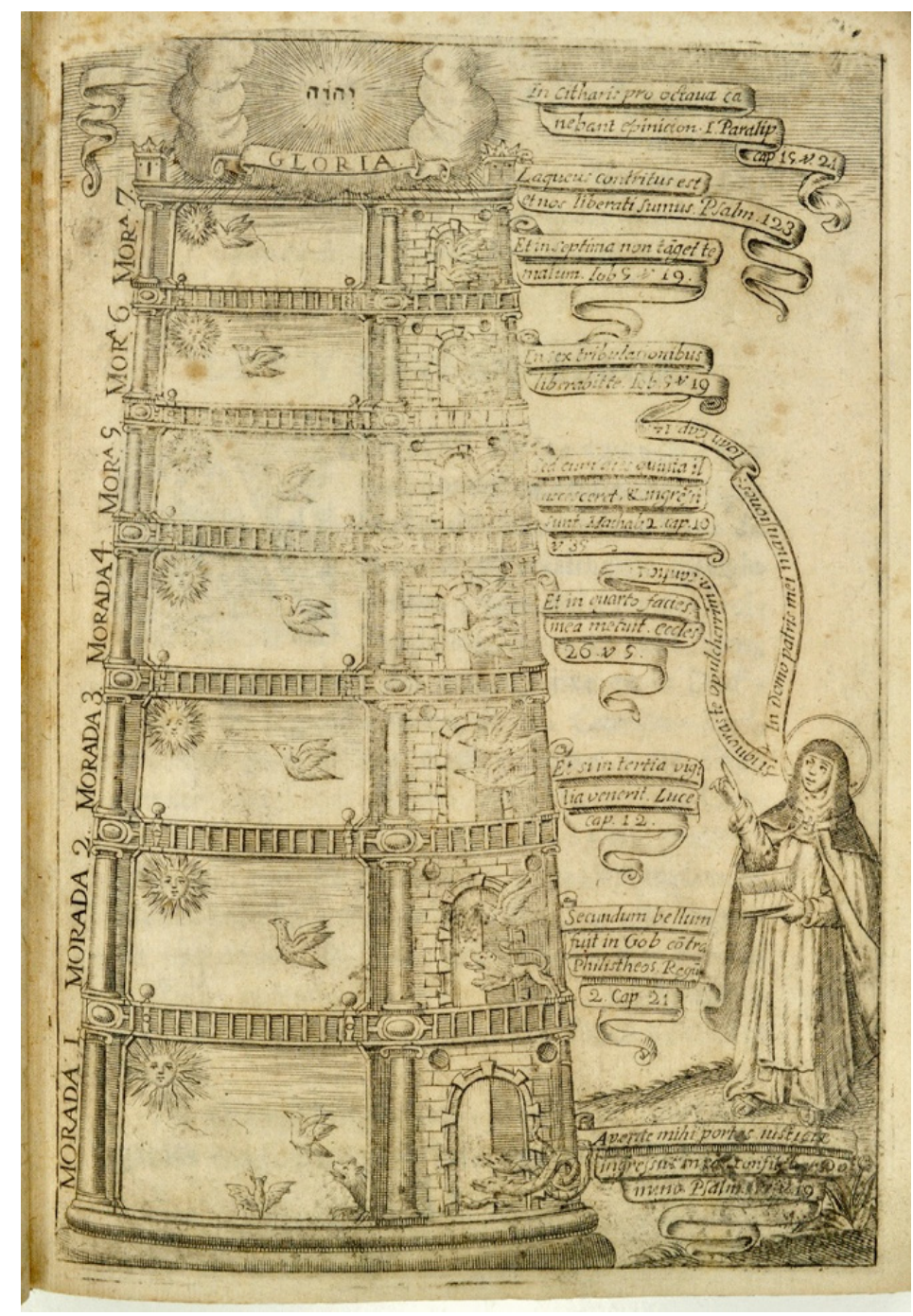

Figure 14. Unidentified artist, The seven dwellings of Saint Teresa, 1677, Antonio González de Reyes, Representaciones de la verdad vestida, misticas, morales, y alegoricas sobre las Siete Moradas de Santa Teresa de Iesús.

The Dormancy of the Virgin shows the significance of landscapes in understanding the meaning of the canvases and, in this case, we could even consider them more important than the representation of the central theme. Beyond this consideration, there is no doubt that the narrative complexity observed in this painting certainly demolishes the belief that the landscape of Peruvian viceregal painting was nothing more than a secondary element or a result of the passive transfer of Flemish landscapes.

To conclude this article, we would like to mention one last canvas that connects us back to where we started with the discourse about the importance of the contemplation of nature in the Andean pastoral. The same rhetorical device that was used for visionary painting reached the theme of the colonial Christian cacique (curaca). These caciques were portrayed as praying in religious scenes or in individual portraits, in which they appeared carrying different objects to confirm their political and social status and Christian condition. Only a small group of these portraits of caciques survived the iconoclastic campaign experienced in Peru after the rebellion of Gabriel Condorcanqui (Tupac Amaru II) in 1781. Examples of them are the portrait of Alonso Chiguan Topa (18th century), who carries a crucifix in 
his right hand, or another of Marcos Chiguan Topa (c. 1720), holding a royal banner that displayed his status as alferez real in religious processions or even his role as an elector of one of the Indian parishes of Cuzco (Wuffarden 2005a, p. 218) ${ }^{36}$.

The canvas that we are dealing with is an eighteenth-century painting conserved in the Museo Inka of Cuzco (Figure 15). It is an indoor space stand-up portrait of a cacique whose identity is unknown. His clothing (he wears a cumbi with tocapus), the crown with mascapaycha on the table, and the coat arms in the upper left corner define his noble status. Based on this coat of arms, Luis Eduardo Wuffarden suggested that this portrait could represent the father of the cacique, Marcos Chiguan Topa (Wuffarden 2005a, p. 118). A much more hermeneutic device was used to indicate the Christian component. In this case, this nobleman makes the gesture of bringing his left hand to his chest. It is not common to find this gesture in other portraits of caciques, nor in portraits of Inca kings, at least not in any of them that have survived to the present. Although it is difficult to interpret the true meaning of this gesture, when we put it in dialogue with the other portraits of caciques, where political and religious components coexist, we could understand it as a motif alluding to penance or devotion. The sociopolitical component of the portrait was well supported, on the one hand, by the presence of the mascapaycha, which showed the royal descent of the character, and, on the other hand, through the noble shield granted by the King of Spain. However, the pious character of this curaca would be more hermeneutic when going through gestural language. Placing the hand on the chest had a long use in European portrait painting and engraving. Such a behavior undoubtedly lent nobility to the person depicted, although, as Andrew Butterfield recalled about the Italian culture of the Renaissance, "the placement of a hand over the chest almost always signifies a state of the soul of deep emotion" (Butterfield 1997, p. 97). This seems to be the direction taken by John Bulwer's explanation of this gesture in his Chirologia, or, The natural language of the hand (1644), the most important manual published on hand gestures in 17th century. His indications seem to validate the emotional character and the proof of humility before God of such behavior. According to Bulwer:

"Lay the hand open to our heart [ ... ] is a garb wherein we affirm a thing, swear or call God to witnesse a truth, and so we seem as if we would openly exhibit unto sense, the testimony of our conscience, or take a tacite oath, putting in security, that no mentall reservation doth basely divorce our words and meaning, but that all is truth that we now protest unto. This expression has been most observed in the ancient Grecians, as Chrysippus saith, who from this natural expression of the Hand, concludes the lodging of the soule to be about the heart." (Bulwer 1644, pp. 88-89)

The relationship between the state of deep devotion, the soul, and the heart explains the recurrent use of this expression within Christian iconography, whether applied to the figure of Christ, the Virgin, or the representation of saints imbued with deep piety and devotion. In some cases, this was directly related to divine love, and the hand on the chest signified the ardent heart. Just as an example, we see this use in an engraving by Theodor van Merlen II (1609-1672) after Abraham van Diepenbeeck (1596-1675), which is dated between 1619-1672 and represents Saint Augustine in the middle of the rapture with his heart burning in his hand (Figure 16) and the other resting on his chest.

In a part of his Spiritual Exercises, Saint Ignatius of Loyola also referred to the pious meaning of this gesture. According to the Jesuit, the retreatant should follow this gesture as a principle that would allow him to abandon sin. Therefore, he had a deep sense of penance, repentance, and humility for the sins committed: "The first Addition-says Saint Ignatius - is that each time one falls into that particular sin or defect, let him put his hand on his breast, grieving for having fallen, which can be done even in the presence of many, without their perceiving what he is doing". 


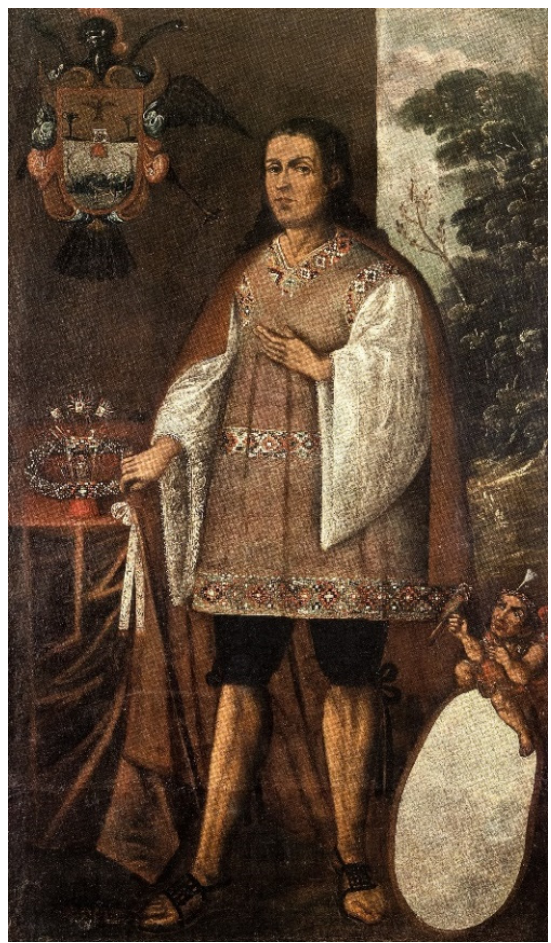

Figure 15. Unidentified artist, Portrait of a cacique, 1700-1730, oil on canvas. Museo Inka, Cuzco. Credit line: Daniel Giannoni from E. Phipps, J. Hecht, C. Esteras Martin, The Colonial Andes: Tapestries and Silverwork, 1530-1830.

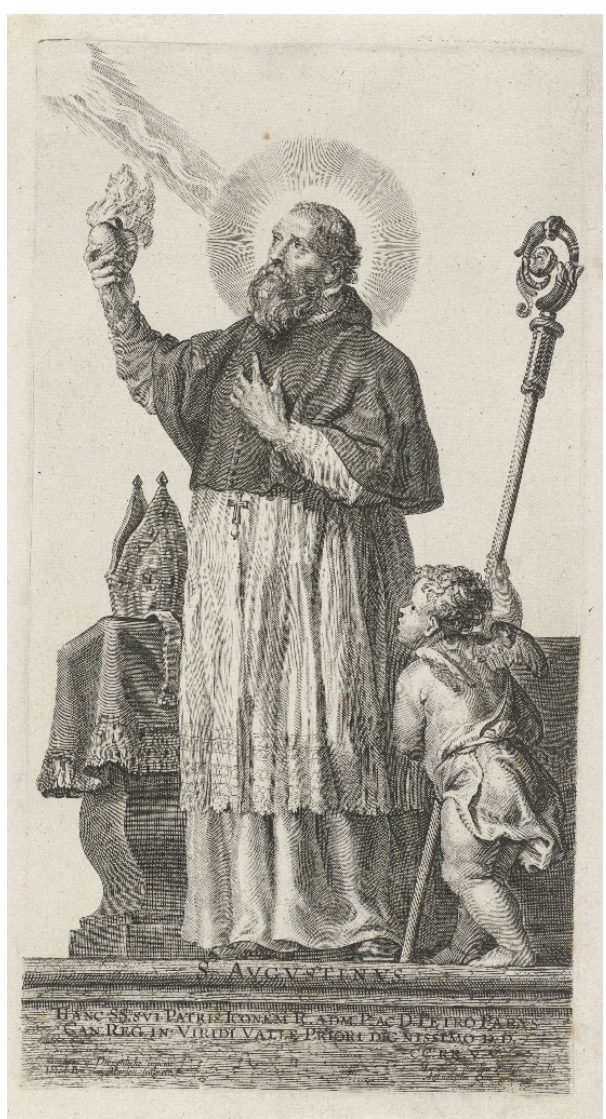

Figure 16. Theodor van Merlen II (1609-1672), after Abraham van Diepenbeeck (1596-1675), H. Augustinus, 1619-1672, engraving, $259 \mathrm{~mm} \times 136 \mathrm{~mm}$. Credit line: Rijksmuseum. 
It is therefore possible to consider that the painter sought to give this curaca a feeling of deep zeal and Christian humility by placing his hand on the heart. As in other religious paintings, the painter included in the background of the composition an opening that allows the viewer to glimpse a leafy landscape, which represents a well-known symbol of the Christian's path of perfection. With his posture, as a symbol of inner spirituality and devotion that is related to the landscape in the background, this unknown curaca declared that he had reached enlightened intellect through contemplation. This way of reaching enlightened understanding through the contemplation of nature, reminds us of the virtuous life of the cacique Don Ignacio mentioned by ${ }^{37}$ the mystic Jesuit Creole Antonio Ruiz de Montoya (1583-1653). In order to illustrate the benefits and the universal scope of the exercise of contemplation Ruiz de Montoya says to another Lima mystic, Father Francisco del Castillo: "I want to remind you of this main Indian called Ignacio, who in the fifty years that he lived as a gentile, kept the natural law in its purity $[. .$.$] " thanks to the$ contemplative exercises (Ruiz de Montoya 1991, p. 156). In other words, before receiving evangelization, Don Ignacio had been able to avoid the traps of the devil by reading the second book of God. Moreover, the indigenous chronicler Pachacuti Yamqui used this same strategy to prove that the first Incas managed to maintain natural law in purity thanks to the contemplation of liber naturae.

\section{Conclusions}

The representation of nature in Andean paintings was symptomatic of the development of a colonial spirituality that was grounded in a context of baroque culturalism and mysticism. Missionary and mysticism discourses established the ideological basis on which the representation of the Flemish landscape took place as a constructor of meaning and as an object capable of communicating spiritual experiences to the viewer.

Representing the landscape in the Andes was not an anodyne and gratuitous gesture; it was linked to a form of materialization of the divine that is based on a Franciscan and Jesuit mystical panentheism that possesses a certain familiarity with the Andean receiver due to the peculiar and divinizing relationship that it maintained with nature.

The viceregal painters were less concerned with treating landscape painting as an extension of the real world. They were not interested in the sensitive aspect of nature, but rather in visualizing its suprasensible essence. The result was a metaphysical characteristic landscape painting that transcended the individual relationship with one's natural environment. Therefore, viceregal painters found in Flemish-style landscapes an idealized and delocalized world that corresponded better to this spiritualized vision of nature.

Likewise, they appropriated certain compositional formulas and their metaphorical uses to develop their own narratives. On many occasions, this element turned out to be the most original in the viceregal paintings, since, through these landscapes, they reformulated the compositional and narrative space of the model engravings.

By constantly intervening in the compositions of imported engravings with the representation of landscapes and making this a kind of compositional archetype, Flemish landscapes paradoxically gave much of their identity to viceregal Andean paintings, both symbolically and aesthetically.

Funding: This research received no external funding.

Institutional Review Board Statement: Not applicable.

Informed Consent Statement: Not applicable.

Data Availability Statement: Not applicable.

Acknowledgments: I owe thanks to the editors, Alena Robin and Lauren Beck, and to the reviewers for the corrections, comments, and suggestions that have contributed to the clarity and content of this article.

Conflicts of Interest: The author declares no conflict of interest. 


\section{Notes}

1 This concept was introduced by Eberhard von Bodenhausen in 1905 and used by Ludwig von Baldass to refer to Patinir's paintings. On the topic of Weltlandschaft, see: (Gibson 1989).

2 Even Francisco Stastny noted that in the 18th century, the Flemish character of landscape painting in Cuzco viceregal painting intensified, assuming a more archaic aspect (Stastny 1997, p. 116).

3 On the issue of the circulation of engravings from northern Europe, especially from Flanders, as well as copies of Flemish engravings made by Parisian publishers, particularly those installed on Rue de Montorgueil, see, for example: (Mesa 1994; Villegas and Torres 2003; Ojeda 2009, 2018; Rodríguez Romero 2009, 2013; Bargellini 2010; Mujica Pinilla 2009). Regarding the importation of Flemish paintings, see: (Villegas and Torres 2003; Siracusano 2005; Van Ginhoven 2015, 2016).

4 Serge Gruzinski also draws attention to the common and almost exclusive use made by viceregal painters of the Flemish-style landscape and the absence of landscapes alluding to the American reality in both New Spanish and Peruvian painting. According to this author, this is due firstly to the controls and restrictions applied by colonial institutions on artistic practices and secondly to the desire of the new viceregal urban elites to seek to include viceregal artistic practices in a Europeanizing universalism (Gruzinski 2010). It should be noted that Gruzinski approaches the Flemish landscape from its political and territorial dimension and does not consider its religious aspect.

5 On this topic, see: (Weemans 2011; Ribouillault and Weemans 2011).

6 In "The Argentine Writer and Tradition", Borges raised the idea of identity through an observation made by Arthur Gibbon: "In recent days I have found a curious confirmation that what is truly native usually and can dispense with local color; I found this confirmation in Gibbon"s History of the Decline and Fall of the Roman Empire. Gibbon observes that in the quintessential Arabic book, the Koran, there are no camels; I believe that, if there were any doubt about the authenticity of the Koran, this absence of camels would suffice to prove that it is Arabic. It was written by Muhammad, and Muhammad, as an Arab, did not have to know that camels were especially Arab; they were part of his reality, he had no reason to distinguish them; instead, a forger, a tourist, an Arab nationalist, the first thing he would have done is lavish camels, camel caravans on every page; but Muhammad, as an Arab, was calm: he knew that he could be an Arab without camels" (Borges 1957). My gratitude to Esperanza López Parada for reminding me of this thought by Borges, which adapts so well to our essay.

7 The Spanish art historian Martin Soria was among the first to establish the link between these pictorial motifs and Andean nature (Soria 1959, p. 34). However, the art historian José de Mesa and Teresa Gisbert have advanced most decisively on this issue, as they were the first to identify the Cuzco painter Diego Quispe Tito as responsible for the introduction of local flora and fauna motifs in Andean viceregal religious painting (Mesa and Gisbert 1982, p. 141; Gisbert 2002, p. 441). In general, historiography largely accepted the link between 18th century Andean painting with local nature (Mesa 1994; Wuffarden 2005b, p. 84; Okada 2014). Furthermore, in the opinion of Francisco Stastny, the integration of these elements in viceregal religious painting is a sample of the transformation process that European prints go through once they were in the hands of Andean painters (Stastny 1967, p. 37). More recently, Teresa Gisbert went even further and studied the causes and motivations that could be behind the landscape transformation of the late 17th century. As a result, she developed the hypotheses that relate the "tropicalization" of Andean religious painting with the idea of Paradise, whether it is a product of missionary discourse extolled by the esteem that the indigenous people had for the tropical zone of Peru (the ancient Inca Antisuyo) or because of the Creole eloquence (Gisbert 2008).

8 Although there are, in the viceregal context, some paintings where it is possible to identify Andean urban spaces and local landscapes - for instance, the Virgin of Monserrat by indigenous painter Francisco Chivantito (1693, church of Nustra Señora de Montserrat, Chinchero, Cuzco), where an idealized landscape of Monserrat is mixed with an aerial view of the Church of Chincheros-they are, however, isolated cases that are not representative of an overall view of landscape painting in Peru.

9 The Franciscan friar Miguel Suárez Figueroa did not hesitate to extoll the skills of Peruvian painters by comparing them with those of the European ones. While commenting on some canvases executed by Creole painters Francisco de Escobar (act. 1649-1676), Pedro Fernández de Noriega (act. second half of the 17th century), Diego de Aguilera (1619-1675), and the freedman Andrés de Liébana (act. second half of the 17th century), he would say that "having all [these paintings] been executed in Peru, there is nothing inferior to curiosity studious of the countries (landscapes) of Flanders, to the curious studies of Rome, nor the excellent refinements of Florence" (Wuffarden 2004, p. 276).

10 The Cantico Espiritual was published for the first time in Spanish in 1627 under the name of Declaración de las canciones que tratan del ejercicio de amor entre el Alma y el Esposo Cristo.

11 Between 1624 and 1757, the Pia Desideria was published 42 times in Latin (Praz 1975, p. 376).

12 On some of these series, see: (Estabridis 2010; Morales Folguera 2009; García Mahiques 1992).

13 An early example of missionary discourse in the Andes is that of Father Domingo Santo Tomás and his "Plática para indios" (Taylor 2003, pp. 27-28).

14 On this topic, see: (Bynum 1975).

15 We use Pierre Duviols's translation (Duviols 1993, p. 36).

16 See: (Mujica Pinilla 2020, pp. 204-12; Wuffarden 2005a; Estenssoro 2003). 
Painters for the Cuzquenian series are unknown; contrariwise, the paintings of Jesús de Machaca were attributed to the painter Pedro Saldaña (Mesa and Gisbert 1982, p. 187).

18 Ursula Härting dates the painting to around 1620 and, probably following the Christie's Auction House attributions in the Apollo Magazine (1977), mentions Abraham Govaerts (1589-1626) as a collaborator (Härting 1989, p. 267). If so, this work would be one of the first Flemish paintings on this subject to include a landscape. However, Christine Van Mulders does not mention other models by other painters before the painting of Rubens and Brueghel as regards the outdoors composition (Van Mulders 2016, pp. 94-95). On the other hand, according to Van Mulders, there was probably an earlier, similar painting by Rubens and Brueghel I: "The innovative composition, as well as the inclusion of [Archdukes Albert and Isabella's Mariemont castle in the landscape], support the hypothesis that the [Dublin's] painting is based on [an earlier] collaborative work by the 'archducal' painters Jan Brueghel I and Rubens [... ]" (p. 94).

The symbolism of these little figures entering the forests or walking along paths in the landscapes has been studied by Michel Weemans (2012, p. 82).

20 Pro suis studiis, Ms. Ambrosiana. G310inf., n.8, 1628, 252r-53r, quoted by (Jones 1988, p. 268).

21 Some examples of these series are the anchorites of the San Jerónimo de Colquepata Church (17th century, secco, Cuzco), of the Recoleta of Cuzco (oil on canvas, s, XVII), and a series from the Recoleta of Sucre (oil on canvas, 17th century). See: (Estabridis 1989; Ojeda 2017).

PESSCA. Correspondence: Sebastian Ferrero and Almerindo Ojeda. https:/ / colonialart.org/archives/locations/peru/departam ento-de-puno/ciudad-de-juli/iglesia-de-san-pedro\#c968a-1053b. Last accessed date: 16 August 2021.

See also: Almerindo Ojeda, “Gallery 8: The Blessed Anchorites of Cuzco”, PESSCA, https://colonialart.org/galleries/gallery-8\# c410a-410b. Last accessed date: 16 August 2021.

Correspondence: Gustavo Adolfo Vives Mejía, PESSCA, 968A/1053B. https:/ / colonialart.org/archives/locations/peru/depart amento-de-puno/ciudad-de-juli/iglesia-de-san-pedro\#c968a-1053b. Last accessed date: 16 August 2021.

The Spiritual Exercises of St. Ignatius of Loyola, Translate by Father Elder Mullan, S.J. I.H.S., New York: Kennedy \& Sons, 1914. Online: Christian Classics Ethereal Library, https://www.ccel.org/ccel/ignatius/exercises.xvi.html. Last accessed date: 16 August 2021.

As for the other three Evangelists, it seems that they are freer compositions inspired by the series of etchings by Egbert van Panderen (1576-1622) after Pieter de Jode I (ca. 1570-1634). In this case, the Evangelists are represented in interior spaces.

For example, a group of engravings by Johannes Wierix (1544-1625) after Maerten de Vos that served Holguín as a visual model for another series of Evangelists in 1724 preserved in the Museum of the Casa de la Moneda. See: Correspondence: Teresa Gisbert PESSCA 236A/236B; 237A/237B; 238A/238B; 239A/239B.

PESSCA 3560A/3560B. Correspondence: Sebastian Ferrero. https:/ / colonialart.org/archives/locations/peru/departamento-depuno/ciudad-de-juli/iglesia-de-san-pedro\#c3560a-3560b. Last access date: 16 August 2021.

The image of the soul as an orchard or enclosed garden cultivated by God is commonplace for many mystical writers. For instance, Santa Teresa said that "it was a great delight to consider my soul as a garden and the Lord walking in it" (Teresa 1877, p. 52). Juli's painting recalls a particular passage from Father Ribadeneyra's biography of Saint Ignatius that says: "Souls capable of virtue, like fertile and lush lands, often sprout vices, and these are like weeds; however, they show virtues and fruits, if they are cultivated." (Ribadeneyra 1583, p. 10v.).

PESSCA 100A/3562B. Correspondence: Sebastian Ferrero. https://colonialart.org/archives/locations/bolivia/departamento-de -la-paz/ciudad-de-la-paz/museo-nacional-de-arte\#c100a-3562b. Last accessed date: 16 August 2021.

31 For this painting, see: Museo de Arte de Lima (MALI) emuseum: https://mali.pe/objects/12993/santa-teresa-de-jesus;jsession id=70E78B597E8988EDDA4D5B825F336A43. Last accessed date: 16 August 2021.

32 These birds in the branches of the trees were related to the well-known stories of the songbirds causing supernatural raptures. Saint Rose had experienced a trance on one occasion herself; when she heard the sweet trilling of some birds, she lost track of time (Meléndez 1681, p. 293; Vargas Ugarte 1961, p. 75). Other Peruvian saints, such as San Francisco Solano (Córdoba y Salinas 1676, p. 251) and San Juan Macías (Meléndez 1682, p. 545), also had mystical experiences with the angelic song of birds.

33 Conserved in Monasterio de Santa Catalina de Siena, Arequipa. Correspondance Almerindo Ojeda, PESSCA 333A/3429B, https:/ / colonialart.org/archives/locations / peru/departamento-de-arequipa/ciudad-de-arequipa/convento-de-santa-catalina\#c333a-3 429b. Last accessed date: 16 August 2021.

One of these four landscapes has a more modern look, which makes us hesitate to include it in the same series with the others. However, they all have similar dimensions and frames. The modern aspect of this canvas is perhaps due to later restorations or repainting.

PESSCA 3573A/3573B. Correspondence: Sebastian Ferrero. https:/ / colonialart.org/archives/locations/peru/departamento-delima/ciudad-de-lima/museo-de-arte-de-lima\#c3573a-3573b. Last accessed date: 16 August 2021. On the curaca's portraits, see (Wuffarden 2005b; Dean 2005).

37 Identified by José Luis Rouillón as Ignacio Piracy of the reducción of Nuestra Señora del Loreto de Guayra. (Ruiz de Montoya 1991, note 107). 


\section{References}

Aguirre, Miguel. 1648. Aprobación. In Tratado de los evangelios que nuestra madre la Iglesia propone en todo el ano desde la primera dominica de adviento, hasta la ultima missa. de Difuntos, Santos de España y añadidos en el nuevo rezado. Explicase el Evangelio y se pone un sermon en cada uno en las lenguas Castellana, y general de los Indios. Edited by Francisco de Ávila. Lima: Imprenta de Pedro de Cabrera.

Bargellini, Clara. 2010. Difusión de modelos: Grabados y pinturas flamencos e italianos en territorios americanos. In Pintura de los Reinos. Identidades Compartidas. Territorios del Mundo Hispánico, Siglos XVI-XVIII. Edited by Juana Gutiérrez Haces. Madrid: Museo del Prado y Palacio Real, Madrid, t. III, pp. 965-1005.

Borges, Jorge Luis. 1957. El escritor argentino y la tradición. In Discusión; Obras Completas. Edited by Jorge Luis Borges. Buenos Aires: Emecé, pp. 151-62.

Bulwer, John. 1644. Chirologia or the Naturall Language of the Hand Composed of the Speaking Motions, and Discoursing Gestures Thereof. Whereunto is Added Chironomia: Or, the ART of Manuall Rhetoricke. Consisting of the Naturall Expressions, Digested by Art in the Hand, as the Chiefest Instrument of Eloquence, by Historicall Manifesto's, Exemplified out of the Authentique Registers of Common Life, and Civill Conversation. London: Tho. Harper.

Butterfield, Andrew. 1997. The Sculptures of Andrea Del Verrocchio. New Haven: Yale Univ. Press.

Bynum, William F. 1975. The Great Chain of Being after Forty Years: An Appraisal. History of Science 13: 1-28. [CrossRef]

Córdoba y Salinas, Diego de. 1676. Vida, virtudes, y milagros del Apostol del Peru el BP Fr. Francisco Solano. Madrid: Imprenta Real.

Dean, Carolyn. 2005. Inka Nobles: Portraiture and Paradox in Colonial Peru. In Exploring New World Imagery: Spanish Colonial Papers from the 2002 Mayer Center Symposium. Edited by Donna Pierce. Denver: Frederick and Jan Mayer Center for Pre-Columbian and Spanish Colonial Art, Denver Art Museum, pp. 80-103.

Durston, Alan. 2007. Pastoral Quechua: The History of Christian Translation in Colonial Peru, 1550-1650. Notre Dame: University of Notre Dame Press.

Duviols, Pierre. 1993. Estudio y comentario etnohistórico. In Relación de antigueda deste reyno del Piru. Pachacuti Yamqui Salcamaygua. Edited by Pierre Duviols and Cesar Itier. Lima: Institut français d'études andines.

Eliade, Mircea. 1987. The Encyclopedia of Religion. London: Macmillan, vol. 10.

Estabridis, Ricardo. 1989. Un cuaderno de grabados de Halbeeck y una serie de anacoretas del Cusco. Kantú: Revista de Arte 6: 37-38.

Estabridis, Ricardo. 2010. Arte y vida mística: El alma y el amor divino en la pintura virreinal. Revista del Museo Nacional del Perú 50: 129-55.

Estenssoro, Juan Carlos. 2003. Del paganismo a la santidad: La incorporación de los indios del Perú al catolicismo, 1532-1750. Lima: Institut français d'études andines.

Esteras Martín, Cristina. 2004. Casket (entry 67). In The Colonial Andes: Tapestries and Silverwork, 1530-1830. Edited by Elena Phipps, Johanna Hecht and Cristina Esteras Martín. New Haven: Yale University Press, p. 232.

Ferrero, Sebastian. 2018. Mirar con los ojos del alma. El misticismo de los Incas en el dibujo cosmológico de Pachacuti Yamqui. In Memoria del Perú. Actas del octavo congreso internacional de peruanistas. Edited by José Antonio Mazzotti and Luis Abanto Rojas. Lima: Revista de Crítica Literaria Latinoamericana, pp. 17-40.

Ferrero, Sebastian. 2021. Have Mercy on Us: Inca Heritage and Christianity in Colonial Cusco. In The Oxford Research Encyclopedia of Religion. Oxford: Oxford University Press.

Flores Ochoa, Jorge, Elizabeth Kuon Arce, and Roberto Samanez Argumedo. 1993. Pintura mural en el sur andino. Lima: Banco de Crédito del Perú.

García Ahumada, Enrique. 1990. La catequesis renovadora de Fray Luis Jerónimo de Oré. In Evangelización y teología en América (siglo XVI), X Simposio Internacional de Teología de la Universidad de Navarra. Pamplona: Servicio de Publicaciones de la Universidad de Navarra, pp. 925-45.

García Mahiques, Rafael. 1992. Gemidos, deseos y suspiros. El Programa Místico de Santa Catalina de Arequipa. Boletín del Museo e Instituto Camón Aznar 48: 83-114.

Gasparini, Graziano. 1978. The Colonial City as a Center for the Spread of Architectural and Pictorial Schools. In Urbanization in the Americas from Its Beginnings to the Present. Edited by Richard P. Schaedel, Jorge Hardoy and Nora Scott Kinzer. The Hague and Paris: Mouton Publishers, pp. 269-82.

Gibson, Walter S. 1989. Mirror of the Earth: The World Landscape in Sixteenth-century Flemish Painting. Princeton: Princeton University.

Gisbert, Teresa. 2002. La identidad étnica de los artistas del Virreinato del Perú. In El Barroco Peruano. Lima: Banco de crédito del Perú, vol. 1, pp. 127-29.

Gisbert, Teresa. 2008. El Paraíso de los Pájaros Parlantes. La Paz: Plural.

Gjurinovic Canevaro, Pedro. 2012. Iconografía de San Martín de Porres. Lima: Universidad de San Martín de Porres.

Gómez, Joaquín. 1749. Breve noticia de la vida, I virtudes del R.P.Fr. Juan Joseph de Peralta, Religioso Menor del Orden de San Francisco, que tomo el Habito, vivio, i murio en el Convento, i Santa Recoleccion de Nra. Sra. De los Angeles, sita extramuros de la Ciudad de Lima, Cabeza, i Metropoli del Reino del Perú. In Las tres jornadas del cielo: Via purgativa, iluminitiva i unitiva; significadas en Gemidos, Deseos, i Suspiros; ordenadas en metrica consonancia para mas suave armnonia al corazón. Edited by Juan de Peralta. Lima: Impr. de la Plazuela de San Christobal.

González, José María Salvador. 2017. La doctrina de San Juan Damasceno sobre la muerte y la asunción de María al cielo, y su posible influencia en las correspondientes iconografías medievales. Eikón Imago 12: 139-68. 
Gracián, Jerónimo. 1616. Apologia del padre Fray Geronymo Gracian. In Obras del P. maestro F. Geronymo Gracian de la Madre de Dios. Madrid: por la viuda de Alonso Martin, pp. 211-14.

Granada, Fray Luis de. 1856. Introducción al símbolo de la Fe. In Obras del v. p. m. fray Luis de Granada: Vida de fray Luis de Granada. Edited by José Joaquín de Mora. Madrid: M. Rivadeneyra.

Gruzinski, Serge. 2010. Las cuatro partes del mundo: Historia de una mundialización. México: Fondo de Cultura Económica.

Härting, Ursula Alice. 1989. Frans Francken der Jüngere (1581-1642): Die Gemälde mit kritischem Oeuvrekatalog. Freren: Luca.

Hernández Miñano, Juan de Dios. 2015. Emblemas morales de Sebastian de Covarrubias: Iconografiá y doctrina de la contrarreforma. Murcia: Universidad de Murcia.

Jones, Pamela M. 1988. Federico Borromeo as a Patron of Landscapes and Still Lifes: Christian Optimism in Italy ca. 1600. The Art Bulletin 70: 261-72.

Joseph del Espíritu, Santo. 1678. Cadena Mystica Carmelitana. Madrid: Oficina de Antonio Gonçalez de Reyes.

Lugo Bertrán, Dorian. 2017. La cocina de Teresa de Jesús: Topos e iconografía de Marta y María de Betania. In Actas del Congreso Internacional «Culturas globalizadas: Del Siglo de Oro al siglo XXI». Edited by Lygia Rodrigues Vianna Peres and Liège Rinaldi de Assis Pacheco. Pamplona: Servicio de Publicaciones de la Universidad de Navarra, Colección BIADIG (Biblioteca Áurea Digital), 39/Publicaciones Digitales del GRISO. pp. 141-57.

Macera, Pablo, and Carmelón Berrocal Evanán. 1999. Flora y fauna de Sarhua: Pintura y palabra. Lima: Universidad Nacional Mayor de San Marcos.

Mariazza Foy, Jaime. 2012. Pintura y naturaleza: El paisaje en la pintura virreinal peruana. Illapa: Revista del Instituto de Investigaciones Museológicas y Artísticas de la Universidad Ricardo Palma 9: 47-55. [CrossRef]

Meléndez, Juan. 1681. Tesoros verdaderos de las Yndias. En la historia de la gran provincia de San Juan Bautista del Peru de el orden de predicadores. Roma: Nicolas Angel Tinassio, vol. II.

Meléndez, Juan. 1682. Tesoros verdaderos de las Yndias. En la historia de la gran provincia de San Juan Bautista del Peru de el orden de predicadores. Roma: Nicolas Angel Tinassio, vol. III.

Mesa, José de, and Teresa Gisbert. 1982. Historia de la pintura cuzqueña. Lima: Fundación A.N. Wiese.

Mesa, José de. 1994. La influencia de Flandes en la pintura del Area Andina. Revista de Historia de América 117: 61-82.

Moncada, Balthasar de. 1757. Descripcion de la casa fabricada en Lima, corte del Perù, para que las señoras ilustres de ella, y las demàs mugeres devotas, y las que desean servir à Dios Nuestro Señor, puedan tener en total retiro, y con toda abstraccion, y direccion necessaria los exercicios de San Ignacio de Loyola. Sevilla: Joseph Padrino, impressor, y mercador de libros.

Morales Folguera, José Miguel. 2009. La celda del Padre Salamanca en el Convento de la Merced de Cuzco. Guía conceptual de la vida religiosa mercedaria en el altiplano peruano del setecientos. Imago. Revista de emblemática y cultura visual 1: 79-97.

Morán de Butrón, Jacinto. 1702. La Azucena de Quito, que broto en el florido campo de la Iglesia en las Indias Occidentales. Lima: Joseph de Contreras Impressor Real.

Mujica Pinilla, Ramón. 1995. El ancla de Rosa de Lima: Mística y Política en torno a la Patrona de América. In Santa Rosa de Lima y su tiempo. Edited by José Flores Araoz. Lima: Banco de Crédito del Perú, pp. 53-211.

Mujica Pinilla, Ramón. 2005. Rosa Limensis: Mística, política e iconografía en torno a la patrona de América. México: Fondo de Cultura Económica/IFEA.

Mujica Pinilla, Ramón. 2009. De centros y periferias: Del grabado europeo al lienzo virreinal peruano. In De Amberes al Cusco El grabado europeo como fuente del arte virreinal. Edited by Cécile Michaud y José Torres Della Pina. Lima: Metrocolor, pp. 71-82.

Mujica Pinilla, Ramón. 2020. El renacimiento inca virreinal: Su arte, emblemas imperiales y teología política. In Arte imperial Inca: Sus orígenes y transformaciones desde la conquista a la independencia. Edited by Ramón Mujica Pinilla. Lima: Banco de Crédito del Perú, pp. 204-12.

Ojeda, Almerindo. 2009. El grabado como fuente del arte colonial: Estado de la cuestión. In De Amberes al Cusco: El grabado europeo como fuente del arte virreinal. Edited by Cécile Michaud y José Torres Della Pina. Lima: Metrocolor, pp. 15-22.

Ojeda, Almerindo. 2017. Los Anacoretas de Colquepata: Fuentes Grabadas. In 4 Festival del Barroco Latinoamericano. Edited by Iván Zignaigo. Cusco: Proyecto Mensura-bilis.

Ojeda, Almerindo. 2018. Impacto del editor parisino Thomas de Leu (1555-1612) sobre el arte colonial. In IX Encuentro Internacional Sobre Barroco: Paisaje y Naturaleza. Edited by Norma Campos Vera. La Paz: Unión Latina, pp. 223-34.

Okada, Hiroshige. 2014. Inverted Exoticism? Monkeys, Parrots and Mermaids in Andean Colonial Art, en Stratton-Pruitt, Suzanne. In The Virgin, Saints, and Angels. South American Paintings 1667-1825 from the Thoma Collection. Milan: Skira, pp. 66-79.

Oré, Luis Jerónimo de. 1598. Symbolo catholico indiano en el cual se declaran los mysterios de la fe contenidos en los tres symbolos catholicos, apostolico, niceno, y de S. Athanasio. Lima: Antonio Ricardi.

Page, Carlos. 2009. La vida de Santa Rosa de Lima en los lienzos del convento de Santa Catalina de Córdoba (Argentina). Anales del Museo de América XVII: 28-41.

Palafox y Mendoza, Juan. 1662. El pastor de Nochebuena: Practica breve de las virtudes, conocimiento facil de los vicios. Bruselas: Casa de Francisco Vivien.

Penhos, Marta. 2015. Santa Teresa de Jesús. In La colección Petrus y Verónica Fernandini: El arte de la pintura en los Andes/The Petrus and Verónica Fenandini Collection: The Art of Painting in the Andes. Edited by Ricardo Kusunoki and Irma Barriga Calle. Lima: Asociación Museo de Arte de Lima (MALI), pp. 104-11.

Praz, Mario. 1975. Studies in Seventeenth-Century Imagery. Roma: Edizioni di storia e letteratura. 
Ribadeneyra, Pedro de. 1583. Vida del P. Ignacio de Loyola. Madrid: Alonso Gomez Impressor de su Majestad.

Ribouillault, Denis, and Michel Weemans. 2011. 'Paysage sacré, Livre de la Nature, Exégèse': Pour une 'reconception' du paysage dans l'Europe de la première modernité. In Le paysage sacré: Le paysage comme exégèse dans l'Europe de la première modernité = Sacred landscape: Landscape as exegesis in early modern Europe. Edited by Denis Ribouillault and Michel Weemans. Firenze: L.S. Olschki, pp. ix-xxxi.

Rodríguez Romero, Agustina. 2009. De París a Cuzco: Los caminos del grabado francés en los siglos XVII y XVIII. Goya: Revista de Arte 327: $132-43$.

Rodríguez Romero, Agustina. 2013. Redes de imágenes y reediciones de estampas: Nuevas aproximaciones al estudio de la circulación de grabados en Europa y América colonial. In Las redes del arte, Intercambios, procesos y trayectos en la circulación de las imágenes. VII Congreso Internacional de Teoría e Historia de las Artes, XV Jornadas CAIA. Buenos Aires: Centro Argentino de Investigadores de Arte, pp. 39-48.

Ross, Waldo. 1992. Nuestro Imaginario Cultural: Simbólica Literaria Hispanoamericana. Barcelona: Ed. Anthropos.

Ruiz de Montoya, Antonio. 1991. Silex del divino amor. Edited by José Luis Rouillon. Lima: Pontificia Universidad Católica del Perú, Fondo Editorial.

Siracusano, Gabriela. 2005. Para copiar las 'buenas pinturas'. Problemas gremiales en un estudio de caso de mediados del siglo XVII en Lima. In Manierismo y transición al Barroco: Memoria del III Encuentro Internacional sobre Barroco. Edited by Norma Campos Vera. La Paz: Unión Latina, pp. 131-39.

Soria, Martín. 1959. Pintura en el Cuzco y el Alto Perú, 1550-1700. Rectificaciones y fuentes. Anales del Instituto de arte americano e investigaciones estéticas 12: 34-64.

Stastny, Francisco. 1967. Breve historia del arte en el Perú: La pintura precolombina, colonial y republicana. Lima: Editorial Universo.

Stastny, Francisco. 1997. La peinture du Pérou colonial. In L'art chrétien du Nouveau Monde. Le baroque en Amérique latine. Edited by Ramón Gutiérrez. Saint-Léger-Vauban: Éditions Zodiaque, pp. 111-19.

Stoichita, Victor. 1996. Pintura y visión religiosa en el siglo de oro español. Madrid: Alianza.

Taylor, Gérard. 2003. El sol, la luna y las estrellas no son Dios: La evangelización en quechua siglo XVI. Lima: IFEA Instituto Francés de Estudios Andinos.

Tercero catecismo. 1585. Tercero cathecismo y exposicion de la doctrina christiana, por sermones: Para que los curas y otros ministros prediquen y enseñen a los Yndios y a las demas personas. Lima: Antonio Ricardo.

Teresa, Saint. 1877. Libro de su Vida. t. I. In Escritos de Santa Teresa. Biblioteca de Autores Españoles. t. LIII. Madrid: M. Rivadeneyra, pp. 23-124.

Unamuno, Miguel de. 1922. Paisaje teresiano. El campo es una metáfora. In Andanzas y visiones españolas. Madrid: Renacimiento.

Van Ginhoven, Sandra. 2015. Guilliam Forchondt and the role of the Greater Netherlands in the dissemination of Flemish art in Latin America. Zeventiende Eeuw 31: 159-78. [CrossRef]

Van Ginhoven, Sandra. 2016. Connecting Art Markets: Guilliam Forchondt's Dealership in Antwerp (c.1632-1678) and the Overseas Paintings Trade. Leiden and Boston: Brill.

Van Mulders, Christine. 2016. Rubens. Works in collaboration Jan Brueghel I \& II. In Corpus Rubenianum Ludwig Burchard. Part XXVII. London: Turnhout: Harvey Miller Publishers.

Vargas Ugarte, Rubén. 1961. Vida de Santa Rosa de Lima. Buenos Aires: Imprenta López.

Villegas, Fernando, and José Enrique Torres. 2003. The influence and uses of Flemish painting in colonial Peru. Courant 7: 12-14.

Weemans, Michel. 2011. Pierres d'achoppement et ruses sacrées. Les paysages exégétiques et anthropomorphes de Herri met de Bles. In Le paysage sacré: Le paysage comme exégèse dans l'Europe de la première modernité = Sacred Landscape: Landscape as Exegesis in Early Modern Europe. Edited by Denis Ribouillault and Michel Weemans. Firenze: L.S. Olschki, pp. 27-50.

Weemans, Michel. 2012. Le paysage comme pérégrination spirituelle et exégèse visuelle. In Fables du paysage flamand. Bosch, Bles, Brueghel, Bril. Edited by Alain Tapié. Paris: Palais des Beaux Arts de Lille, Somogy, Editions d'art. pp. 77-83.

Wuffarden, Luis Eduardo. 2004. La Catedral de Lima y el 'triunfo de la pintura'. In La Basílica Catedral de Lima. Edited by Guillermo Lohmann Villena. Lima: Banco de Crédito del Perú, pp. 240-317.

Wuffarden, Luis Eduardo. 2005a. La descendencia real y el 'renacimiento inca' en el virreinato. In Los incas, reyes del Perú. Edited by Thomas Cummins. Lima: Banco de Crédito del Perú, pp. 175-251.

Wuffarden, Eduardo. 2005b. Las escuelas pictóricas virreinales. In Perú indígena y virreinal. Spain: Museu Nacional d'Art de Catalunya, pp. 80-87.

Wuffarden, Luis Eduardo. 2016. Dormición de la Virgen. In Arte Colonial. Colección Museo de Arte de Lima. Edited by Ricardo Kusunoki and Luis Eduardo Wuffarden. Lima: Gráfica Biblos, pp. 116-17.

Zugasti, Miguel. 2000. Vuela mi pluma cual ligera garza, Don Juan de Palafox y Mendoza y la literatura. In Palafox: Iglesia, cultura y Estado en el siglo XVII: Congreso Internacional IV Centenario del Nacimiento de Don Juan de Palafox y Mendoza. Pamplona: Universidad de Navarra, pp. 283-311. 